Article

\title{
Raising the Curtain in People Management by Exploring How Sustainable HRM Translates to Practice: The Case of Lithuanian Organizations
}

\author{
Živilè Stankevičiūtè *(1) and Asta Savanevičienè \\ School of Economics and Business, Kaunas University of Technology, Gedimino g. 50, LT-44249 Kaunas, \\ Lithuania; asta.savaneviciene@ktu.lt \\ * Correspondence: zivile.stankeviciute@ktu.lt; Tel.: +370-650-11-505
}

Received: 31 October 2018; Accepted: 20 November 2018; Published: 22 November 2018

\begin{abstract}
Arguing for the necessity to re-think human resource management (HRM), as human resources are becoming scarce, HRM practices themselves can be even harmful for employees, and the mainstream HRM is more interested not in the employee well-being, but in the search for the link between HRM and performance, the paper introduces sustainable HRM as an alternative approach to people management. Sustainable HRM is seen as a design option, which allows one to maintain, renew and restore human resources. Although previous works have broadened the understanding of the meaning given to sustainable HRM and its core characteristics, research into how sustainable HRM translates into practice is still lacking. Thus, the purpose of the paper is to reveal the practices through which 11 characteristics of sustainable HRM are expressed in real people management in organizations. In doing this, qualitative data were collected from Lithuanian organizations using semi-structured interviews with 19 human resource (HR) managers. The research indicated a variety of applied practices, which differ by maturity. Care of employees, profitability, external partnership, fairness and equality, and employee development were revealed as the characteristics of sustainable HRM most explicitly expressed through HRM practices. Nonetheless, the organizations need more heterogeneous HRM activities, which simultaneously consider the economy, environment, society, and human aspects.
\end{abstract}

Keywords: sustainable human resource management; characteristics of sustainable human resource management; practices of sustainable human resource management; sustainability

\section{Introduction}

Over the last three decades, the field of HRM has made a significant progress as a core business function [1] and as an academic discipline [2]. Despite these achievements, recently, the debate about the future of HRM has widely expanded [3,4] calling to re-think the main direction of HRM. Such call relies on previous studies, which typically were focused on the search for the link between HRM and performance [5-9]. Research along these lines has investigated why and how organizations achieve their goals implementing individual or bundles of HRM practices [6]. Financial goals or financial outcomes were treated as the core elements of added value generated by HRM, whereas employee perspective in terms of well-being was largely neglected [10]. The needs, preferences and perspectives of employees were less considered [3]. Generally speaking, for a long time the prevailing conclusion has been voiced as "the sole purpose of HRM is ultimately to improve the financial return to the shareholders" [2] (p. 431). However, recently the situation has been changing as internal and external challenges impel the organizations to re-think strategies and practices of HRM [11]. 
Obviously, the search for new HRM framework is largely related to the fact that the environments in which the organizations operate are changing very rapidly and not always in the direction desirable by business. Environmental pollution, financial crises, shortage of resources, and public awareness are just a few examples of external challenges the organizations have to deal with in order to maintain their social legitimacy or "license to operate" [12]. None the less relevant are internal factors related to employees, such as a lack of labor force, increasing work-related health problems $[13,14]$ or decreasing employee engagement [15]. The vast majority of the mentioned internal issues are outcomes of HRM. In this context, Ehnert [16] refers to "side and feedback effects" of HRM on employees, meanwhile Mariappanadar [17-19] introduces the concepts of "harm" of efficiency-oriented HRM on stakeholders and "externalities". Clearly, a business willing to survive cannot neglect the self-induced negative outcomes of HRM, which may potentially affect the future situation of business. It is necessary to change the approach towards people management if organizations want to have employees as resources for doing business in the future [12]. Following the suggestion that "human resource should be managed sustainably" [18] (p. 168), the concept of sustainable HRM was introduced $[16,20,21]$. Sustainable HRM links the idea of sustainability to people management seeing that resource regeneration, development and renewal are at the heart of sustainability [22,23].

Thus, sustainable HRM is seen as a framework to cope with a huge range of challenges such as human resource scarcity or work-related health problems. In addition, sustainable HRM turns attention to needs, preferences and perspectives of employees. Thus, the mentioned intention and potential of sustainable HRM serve as arguments for the importance of sustainability in people management and underline the relevance of exploring the sustainable HRM itself.

Sustainable HRM is quite a new concept, which is still at the pioneering if not emerging phase [13] and reflects a lot of the attempts to link sustainability to HRM. Several definitions were proposed [13,20], however, the one provided by Ehnert et al. [24] seems to be the most influential and covering the whole essence of construct:

"The adoption of HRM strategies and practices that enable the achievement of financial, social and ecological goals, with an impact inside and outside of the organization and over a long-term time horizon while controlling for unintended side effects and negative feedback" (p. 90).

Clearly, previous research in sustainable HRM has broadened the understanding about underlying rationalities and reasoning for linking sustainability and HRM, also about the meaning of emerging construct $[22,25,26]$. Few studies $[16,20,27]$ have sought to provide theoretical frameworks of sustainable HRM including the theoretical background, context, practices, and outcomes involved in ongoing debate on sustainable HRM. Moreover, several studies have explicitly or implicitly provided the main characteristics of sustainable HRM $[16,20,27,28]$. Although there is no general agreement on these core characteristics, the literature generally sets what distinguishes sustainable HRM from HRM in general. Such consensus is critical, whereas characteristics could be used by scholars and practitioners as leading indicators for measuring sustainable HRM. Still, in spite of the growing number of theoretical publications on sustainable HRM [29-31], the lack of empirical evidence as regards the practical manifestation of sustainable HRM in concrete business organizations is obvious [24]. Moreover, prior research has largely neglected research in organizations and the data were mainly taken from social responsibility reports. The paper seeks to close the gap by identifying how the theoretical concept of sustainable HRM is being translated into practice by various business organizations. The data obtained from semi-structured interviews are used.

The purpose of the paper is to increase the knowledge of sustainable HRM by revealing the practices through which 11 characteristics of sustainable HRM are expressed in real people management in organizations. The paper is based on the qualitative data collected in 19 Lithuanian organizations, which are members of the Lithuanian Association of Responsible Business or declare commitment to sustainability providing sustainability reporting. The interviewees were employees, 
responsible for HRM or managers of organizations, in the absence of a particular position. However, for further briefness a general term "HR manager" is used.

The paper contributes to the literature of sustainable HRM in several ways. Firstly, the paper provides empirical evidence on how sustainable HRM is embedded in organizations. The answer to the question how theoretical characteristics of sustainable HRM are translated to the practical people management level is provided. Thus, the paper continues the research stream that has investigated the sustainable HRM dimensions [32,33] and practices [16,24,31]. Certainly, the paper implies a different perspective and reveals the practices of sustainable HRM as they are seen from the HR managers' angle. Secondly, from the empirical point of view, the paper responds to Ehnert et al.'s [12] claim that the research should be conducted in the organizations and the data should not be taken from the social responsibility reports. Thirdly, it is well established in the current literature that sustainable HRM has a double role: (a) to contribute to implementing sustainability in organizations; (b) to make HRM systems sustainable per se [34]. The paper contributes to the last research stream addressing how characteristics of sustainable HRM are expressed and implemented by organizations. Fourthly, the paper responds to Pfeffer's [14] call to treat the social dimension of corporate sustainability seriously, instead of overlooking, and especially from the HRM perspective, as sustainability has received comparatively little attention from HR researchers [35]. In doing this, the paper contributes to theory enrichment not only in the field of sustainable HRM, but also in the field of corporate sustainability. Finally, the paper follows the approach that national context affects the approach to sustainable HRM [2,27]. Given the above, the paper increases the knowledge of sustainable HRM meaning by providing insights from Lithuanian organizations. Thus, in general the paper responds to the call of Ehnert et al. [12] trying to shed light on how sustainability can be integrated in the people management in organizations.

The paper commences with a brief outline of the rationale for linking sustainability and HRM and then presents the construct of sustainable HRM. Next, the paper proceeds by explaining the method of the research. Further, the results on how a particular characteristic of sustainable HRM is expressed and implemented in organizations are described. Next, the discussion part follows. Last, the paper offers some general conclusions before indicating some future research avenues.

\section{Sustainability as a Concept for HRM}

Sustainability is not a new concept, having deep roots already in times of Aristotle [36]. However, it became popular only after the World Commission on Environment and Development in 1987 [37] has defined sustainable development as "development that meets the need for the present without compromising the ability of future generations to meet their own needs" (p. 43). This definition at the societal level was translated to the business level arguing for corporate sustainability [38-41]. According to Dyllick and Hockerts [40], corporate sustainability relies on three things: integration of economic, social and ecological aspects, which are inter-related and influence each other in multiple ways; integration of short-term and long-term aspects; and consumption of income and not the capital. Generally speaking, corporate sustainability means that organizations need to control their impact on various economic, social and ecological environments [24] and that business success is not defined solely in financial terms, but also in terms of social and environmental outcomes [42].

Turning to HRM, it seems that during the same period of time when debates around corporate sustainability were blooming, theory and research on HRM "has established itself, gained popularity, and developed a strong position" [2] (p. 427). The research interest has been mainly focused on answering the question on how HRM and performance are linked [6]. Based on empirical research, the prevailing conclusion sounded more than optimistic: HRM has a positive effect on performance in terms of operational and financial outcomes [9]. In the meantime, human resources outcomes, in terms of employee well-being, were largely neglected or seen only as a key mediator between HRM and performance [2,9]. However, gradually internal and external challenges, such as labor force shortages, ageing society [16], and employee health problems [43] started forcing practitioners and researchers to switch the approach by turning back to employees "as critically important asset to 
the organization" [3] (p. 146). From around 2000 onward, scholars try to employ in HRM a more employee-centered approach. However, bringing the $\mathrm{H}$ back to HRM requires a "different approach to HRM" [11] (p. 22) or even a paradigm change [44].

Although various solutions have been proposed for re-thinking HRM [11], several scholars argue for introducing sustainability to HRM $[16,20,45,46]$. The essential cause of linking sustainability to HRM could be illustrated by the following quotation: "sustainability refers to maintaining, renewing or restoring a specific resource so that what we currently use and enjoy will still be available to use and enjoy in the future" [22] (p. 1). Given the above, it a survival strategy for organizations to deal with people in such way that current and potential employees would have (a) a wish to work for a particular organization; (b) the ability to perform duties in a manner appropriate for business; and (c) the opportunities to work in terms of health, stress or work-life balance [12]. In essence, sustainability implementation in HRM offers solutions to challenges and allows re-focusing attention to employee. Although research linking sustainability and HRM is emerging under different labels "green HRM" [47-49], "socially responsible HRM" [50-53], "sustainable work systems" [45,46,54], the paper focuses only on the construct of sustainable HRM.

\section{Outlining Sustainable HRM}

At the beginning, it should be acknowledged that due to a short history sustainable HRM "does not have clear lines and directions of more mature areas of study" [13] (p. 231). Nonetheless, sustainable HRM is seen as an alternative approach to people management [27] and extension of strategic HRM $[16,44,55]$. Essentially, sustainable HRM is an umbrella term that covers multiple dimensions, diverse contexts, and multiple levels of analysis [13] and can be understood in terms of a number of complimentary frameworks [27]. Because of such perception, recently the field of HRM has rapidly evolved tackling different aspects [56-61]. The following section is organized in a way to briefly reveal the development of the construct, the meanings given to sustainable HRM, as well as the underlying approaches, characteristics and practices of sustainable HRM. Seeing that a comprehensive analysis of all publications in the field of sustainable HRM is beyond the scope of this paper, the literature review is limited mostly focusing on the meaning of sustainable HRM and its core characteristics, as these characteristics are relevant for the empirical part of the paper.

It seems that sustainable HRM has evolved tackling different aspects or using various lenses for theorizing on the construct $[16,27,28,62-67]$. Initially, sustainable HRM was developed in the context of sustainable resource management referring to organizations as open systems, resource-dependent systems, when "each system is thus both dependent on other systems and has other systems depending on it" [36] (p. 55). In parallel, sustainable HRM was conceptualized following normative understanding of sustainability as a moral, ethical value building in line with the definition of the World Commission on Environment and Development [20]. Subsequently, reframing, revision and extension of the mainstream principles of strategic HRM were used for the introducing and exploring sustainable HRM $[16,28]$. Moreover, the analysis regarding sustainable HRM from a stakeholder perspective has broadened the understanding on the value sustainability can add to various actors not only in the domain of people management but also in corporate management [55]. Eventually, the negative externality and stakeholder harm theory are being used as an underlying approach for sustainable HRM [65-67]. As the paper argues that sustainable HRM represents as new approach to people management, it is important to understand the core message of sustainable HRM. Referring to the literature, the main underlying objectives of sustainable HRM are further explained.

The first objective of sustainable HRM is “to sustain, develop, and reproduce an organization's human and social resource base e.g., with the help of mutual exchange relationships" [25] (p. 14). This objective has its roots in an open-system approach, according to which the organization operates in a sustainable way if its resource reproduction divided by resource consumption equals one [36]. The main assumption is that it is economically rational for business to act sustainably if the resources are scarce [36]. Transferring to the HRM context, it is economically rational for organizations to balance 
the consumption and reproduction of human resources by cooperating with business environments, as environments are "sources of resources". Based on this understanding, Müller-Christ and Remer [62] defined sustainable HRM as "what companies themselves have to do in their environments to have durable access to skilled human resources" (p. 76).

The second objective underlies the necessity to "to evaluate and assess negative effects of HR activities on the HR base and on the sources for HR" [25] (p. 14). This objective relies on the conflicting outcome perspective by acknowledging that HRM can have a negative effect on employees and other stakeholders [10]. The negative externality and stakeholder harm theory provides an in-depth explanation of the need for controlling the impact of HRM on employees and serves as an underlying approach for sustainable HRM [17-19,65-67]. Negative externality refers to "something that costs the organizations less for their actions or business practices than they save" [66] (p. 184). Following the social cost theory, the costs are imposed on the weaker members of society, such as employees and their family members [67], moreover, negative externalities have a negative impact on society in general [66]. Thus, sustainable HRM has been suggested for reducing the harm on employees [65-67]. Sustainable HRM is built on the synthesis effect, where organizations can use the HRM practices to maximize their profits, and in addition reduce the harm of HRM practices on the stakeholders because "these two polarities are not mutually exclusive but are rather mutually reinforcing" [67] (p. 2). Thus, sustainable HRM could be defined as "those HR systems or bundles that enhance both profit maximization for the organization and also 'reduce the harm' on employees, their families and communities" [67] (p. 313).

The third objective is about balancing "the ambiguities and the duality of efficiency and sustainability over a long-lasting calendar time" [25] (p. 14). This objective relies on the paradox theory, which was introduced by Ehnert [16,23] as a theoretical background for operationalizing sustainable HRM seeing paradox as "contradictory yet interrelated elements that exist simultaneously and persist over time" $[23,68]$. The tensions between short- and long-term effects, the tensions between economic rationality and relational rationality, and the tensions between deploying human resources efficiently and sustaining them are the examples of key paradoxes of sustainable HRM [23].

It seems that the mentioned core objectives are in line with the stakeholder theory arguing that an organization has the duty to take care of all stakeholders [55]. Thus, under the Swiss approach with regard to sustainable HRM, sustainability is perceived as a mutual benefit referring to employers and employees as equal partners: satisfaction of individual needs and maintaining of competitiveness of an organization is supported by sustainable HRM [20,21]. Accordingly, sustainable HRM is described as "the long-term socially and economically efficient recruitment, development, retainment and disemployment of employees" [20] (p. II). For the purposes of the paper it should be mentioned that the Swiss approach was developed as the synthesis of theoretical and empirical insights, revealing the heterogeneous understanding of sustainable HRM in different European countries.

The Respect, Openness and Continuity (ROC) model [28] can be used as an example of sustainable HRM perception, which incorporates the mentioned three underlying objectives and uses the lenses of stakeholder theory. According to it, sustainability in HRM is characterized by the renewed focus on respect for the employees (Respect); environmental awareness and outside-in perspective on HRM (Openness); and a long-term approach, both in terms of economic and societal sustainability and with regard to individual employability (Continuity).

Generally talking, the paper adopts the position of Ehnert et al. [24] concluding that the following two components are at the heart of sustainable HRM: (1) the recognition of multiple, potentially contradictory, economic, ecological and social goals; (2) and complex interrelations between HRM systems and their internal and external environments with emphasis on relationships, which allow the long-term reproduction of resources and control externalities.

Continuing the literature review on sustainable HRM and following the aim of the paper, it is important to reveal the core characteristics and practices of sustainable HRM. Characteristics provide an explanation about features of the construct and enable researchers and practitioners to distinguish one construct from another, thus providing evidence that "sustainable HRM literature represents a 
new approach to the management of people" [27] (p. 1080). The characteristics of sustainable HRM explain how sustainability can be used for HRM. They also describe what HRM should look like in order to deserve the attribute 'sustainable'. Generally speaking, despite the progress towards the features of sustainable HRM [23,32], the issue of the characteristics still remains underdeveloped.

Literature review allows stating that researchers choose different ways to introduce the characteristics of sustainable HRM. Some of them appear to provide the characteristics by describing the construct per se. For instance, Cohen et al. [34] refer to equity, well-being and employee development as the main dimensions in designing sustainable HRM. De Prins et al. [28] argue that respect of people, openness by following the outside-in perspective and continuity by keeping the long-term approach are the underlying attributes of sustainable HRM. According to Zaugg et al. [20], employees' self-responsibility and participation in decisions while HRM operates as a "guardian" of human resources with the objective to support the employees serve as characteristics of sustainable HRM. Other writers focus on the features which differentiate sustainable HRM from the mainstream HRM literature, including strategic HRM, and in that vein disclose the characteristics. Therefore, treating organizational outcomes in a broader sense rather than just financial outcomes by including human and social outcomes [27] and acknowledging not only positive but also the negative effects of HRM on different stakeholders $[69,70]$ are the characteristics of sustainable HRM. Ultimately, besides the implicitly expressed characteristics of the construct, some researchers do it explicitly. Zaugg [21] incorporates the following characteristics in his sustainable HRM framework: employee participation, competency and knowledge orientation, strategy orientation, flexibility, value orientation, stakeholder orientation, and building mutually trustful employee-employer relationships. Ehnert [71] introduced some other characteristics: exploring short-term as well as long-term effects as well as side and feedback effects; extending the notion of success by considering economic, social and ecological objectives; considering moral, ethical positions as well as economic arguments; fostering the ability of HRM to develop and sustain the HR base and environments from within; and balancing paradoxes, dualities, dilemmas, and tensions. Several years later, Ehnert [23] provided a slightly different list of characteristics in terms of their titles including: long-term oriented; partnership-oriented; substance and self-sustaining oriented; impact-control oriented; multiple-bottom lines-oriented; and paradox-oriented. More recently, based on qualitative study Järlström et al. [32] introduced four dimensions as sustainable HRM characteristics, namely justice and equality, transparent human resource practices, profitability and employee well-being.

Drawing on the previous literature, the paper proposes 11 characteristics of sustainable HRM, namely: long-term orientation, care of employees, care of environment, profitability, employee participation and social dialogue, employee development, external partnership, flexibility, compliance beyond labor regulations, employee cooperation, fairness and equality.

At first sight, it could be argued that the mentioned characteristics are quite similar to the features of the mainstream HRM. However, the sustainable HRM discussion has taken these characteristics to a new level as characteristics of sustainable HRM have an entirely extended content. Sustainability attributes are part of these characteristics. The characteristics are in line with and reflect the integration of economic, social and ecological aspects, focus on the long-term perspective and rely on consumption of income rather than capital [40]. Employee development could serve as a good example for exploring the extended content. Thus, employee development as a characteristic of sustainable HRM focuses on the development of capacities needed for a longer perspective in terms of better performance and future employability. Furthermore, the expenses for development are not severely cut back during economic crises seeing long-term business problems due to the shortage of employee competencies. Finally, employee training as a process is organized considering employee work-life balance.

However, going further, it is not sufficient to identify the core characteristics; equally important is to explore how these characteristics are embedded in HRM. The main way for translating characteristics into real business life is via HRM practices. Thus, theoretical writings provide a broad variety of practices related to the sustainable HRM discussion, namely collaborative 
human resource development, career management, performance appraisal, reward management, employee direct voice and participation [72-75]. Additionally, the ROC model, provided by De Prins [28], introduces horizontal/thematic (e.g., diversity, engagement, employee participation) and vertical/transformational practices (e.g., selection, training, development) as a part of sustainable HRM. Turning to empirical evidence, the literature is scanter. To the best of the authors' knowledge, only several attempts have been made to identify the HRM practices through which sustainable HRM is expressed. The most comprehensive research was done by Ehnert [16] who analyzed the websites of companies and summarized the practices of sustainable HRM into the following four categories: attracting talent and being recognized as an "employer of choice"; maintaining a healthy and productive workforce; investing into skills of the current and future workforce; and creating employee trust, employer trustworthiness and sustained employment relationships. In a same manner, the research of Zaugg et al. [20] and Zaugg [21] also reveals sustainable HRM practices by analyzing instruments of sustainable HRM. From the broad perspective, the research of Järlström et al. [32] indicated some practices as examples of how top managers construct the concept of sustainable HRM. A case of a German bank is provided as an example of sustainable HRM practices by Hoeppe [76]. Further, Diaz-Carrion et al. (2018) based on sustainability reports, revealed a system of sustainable HRM formed by six policies and 98 practices [31]. Given the above, the empirical part of the paper addresses the HRM practices through which the theoretical concept of sustainable HRM, namely the characteristics of sustainable HRM, are expressed.

\section{Materials and Methods}

\subsection{Context of the Study}

Based on the literature review, Beer et al. [2] concluded that geographic location affects how HRM is understood. Kramar [27] announced the same finding concerning sustainable HRM arguing that national context impacts on the approach to sustainable HRM. This conclusion was strongly reinforced by the study of Zaugg et al. [20] when results obtained in eight European countries differed. Recently, Diaz-Carrion et al. [53] have underlined that "countries have differently incorporated CSR into their HRM systems, which has led to the existence of different models of SR-HRM across Europe" (p. 15). Following the idea that national context matters in examining sustainable HRM, Lithuania was chosen for this research.

Thus, the context of the study is Lithuania, which does not have a long history in the field of sustainability. The Lithuanian National Strategy for Sustainable Development was approved in 2003 (updated in 2009) stipulating that the Strategy implementation reports shall be drafted every two years [77]. However, it seems that the majority of businesses in Lithuania responding to national, EU and worldwide challenges accepted the rules of new game by committing or declaring the commitment to sustainability. This assumption relies on several facts.

Firstly, some administrative and formal changes are visible in the business community. A fair number of the organizations started providing reports according to the Global Reporting Initiative (GRI) standards or other frameworks. In 2013, the Association of Responsible Business was established with a mission to promote the development of responsible business as the prerequisite for sustainable development in Lithuania. Moreover, the network of sustainable development and corporate social responsibility specialists "CSR Network" Lithuania" was established in 2013 with the aim to unite knowledge, expertise and efforts for promoting social and environment responsibility of private and public sectors and citizens of Lithuania [78]. The growing number of sustainability-committed organizations enables the Ministry of Social Security and Labour of the Republic of Lithuania to implement the initiative of the National Responsible Business Award (NRBA). In 2018, three nominations were announced: Workplace of the Year, The Most Community-Led Company and Environmental Company of the Year. Each of the NRBA nominations is divided into three categories and separate awards are given to micro, small or medium companies; 
large companies; and international companies or their affiliates/representative offices operating in Lithuania. The biggest achievers are honored conferring the title of a Socially Responsible Company. Furthermore, additional awards will be given in 2018 for achievements in creating jobs for older people as well as for activities that help return the Lithuanian citizens who emigrated and to integrate them into the labor market [79]. In general, all these nominations are related to and reflect the quality of HRM in organizations. Thus, an assumption could be made that HRM has already taken some steps towards creating a sustainable HRM system.

Secondly, Lithuania faces highly strung demographical issues: since 1990, the number of residents living in Lithuania has dropped by 883 thousand, which constitutes about 24 percent of the entire population. The vast majority of the number is due to emigration. Moreover, based on the data provided by Statistics Lithuania, from 2004 almost 619 thousand residents left Lithuania and only 194 thousand people arrived [80]. Such information leads to the conclusion that in order to have access to the labor force in the future business also needs to re-think HRM by integrating sustainability aspects.

Thirdly, in the Global Sustainable Competitiveness index, which evaluates a wide range of sustainability-related measures [81], Lithuania rated number 23 among the 176 countries ranked.

Considering all the mentioned facts and intensive and growing commitment to sustainability, Lithuania offers an interesting context for studying how sustainable HRM is translated into practice.

\subsection{Data Sample and Collection}

Organizations, which are members of the Lithuanian Association of Responsible Business or provide sustainability reporting according to one of the well-known frameworks such as Global Reporting Initiative (GRI) or Global Compact, were invited to take part in the research. The core idea was that these organizations are familiar with the sustainability-related thinking. The invitation was sent to 59 organizations. A total of 19 organizations agreed to join the research. Organizations represent various industries: manufacturing, trade, consultancy business, and services. All of them were from the private sector.

The complexity of the topic, lack of existing data, and exploratory nature of the research necessitated a qualitative approach [82]. As the study focused on the activities through which sustainable HRM is implemented, HR managers were chosen as the people who can provide comprehensive and precise data. The study draws on data collected via semi-structured interview. Table 1 outlines the profiles of organizations and HR managers:

Table 1. Profile of organizations and respondents.

\begin{tabular}{cccccc}
\hline $\begin{array}{c}\text { Respondent } \\
\text { Number }\end{array}$ & $\begin{array}{c}\text { Organization } \\
\text { Industry }\end{array}$ & $\begin{array}{c}\text { Organization } \\
\text { Size }\end{array}$ & $\begin{array}{c}\text { Respondent } \\
\text { Gender }\end{array}$ & $\begin{array}{c}\text { Respondent } \\
\text { Age }\end{array}$ & $\begin{array}{c}\text { Respondent } \\
\text { Background }\end{array}$ \\
\hline R1 & Services & Approx. 200 & female & 54 & Master in HRM \\
\hline R2 & Services & Approx. 200 & female & 35 & $\begin{array}{c}\text { Master in } \\
\text { management }\end{array}$ \\
\hline R3 & Trade & Approx. 90 & female & 44 & $\begin{array}{c}\text { Master in } \\
\text { management }\end{array}$ \\
\hline R5 & Manufacturing & Approx. 200 & female & 34 & $\begin{array}{c}\text { Master in } \\
\text { management }\end{array}$ \\
\hline R6 & Consultancy & Approx. 10 & male & 57 & $\begin{array}{c}\text { PhD in } \\
\text { management }\end{array}$ \\
\hline $\begin{array}{c}\text { Relations and } \\
\text { communication } \\
\text { agency }\end{array}$ & Approx. 15 & male & 51 & $\begin{array}{c}\text { Master in } \\
\text { communication }\end{array}$ \\
\hline
\end{tabular}


Table 1. Cont.

\begin{tabular}{|c|c|c|c|c|c|}
\hline $\begin{array}{l}\text { Respondent } \\
\text { Number }\end{array}$ & $\begin{array}{l}\text { Organization } \\
\text { Industry }\end{array}$ & $\begin{array}{l}\text { Organization } \\
\text { Size }\end{array}$ & $\begin{array}{c}\text { Respondent } \\
\text { Gender }\end{array}$ & $\begin{array}{c}\text { Respondent } \\
\text { Age }\end{array}$ & $\begin{array}{l}\text { Respondent } \\
\text { Background }\end{array}$ \\
\hline R7 & Consultancy & Approx. 20 & male & 56 & $\begin{array}{l}\text { Bachelor in } \\
\text { engineering }\end{array}$ \\
\hline R8 & Manufacturing & Approx. 100 & female & 28 & Master in law \\
\hline R9 & $\begin{array}{l}\text { Insurance } \\
\text { company }\end{array}$ & Approx. 200 & female & 34 & $\begin{array}{c}\text { Master in } \\
\text { management }\end{array}$ \\
\hline R10 & Services & Approx. 200 & female & 52 & $\begin{array}{l}\text { Master in } \\
\text { economics }\end{array}$ \\
\hline R11 & Services & Approx. 150 & female & 30 & $\begin{array}{c}\text { Master in } \\
\text { management }\end{array}$ \\
\hline $\mathrm{R} 12$ & Trade & Approx. 50 & female & 41 & $\begin{array}{c}\text { Master in } \\
\text { psychology }\end{array}$ \\
\hline R13 & Manufacturing & Approx. 200 & female & 32 & $\begin{array}{c}\text { Master in } \\
\text { management }\end{array}$ \\
\hline $\mathrm{R} 14$ & Consultancy & Approx. 45 & male & 28 & $\begin{array}{l}\text { Bachelor in } \\
\text { management }\end{array}$ \\
\hline R15 & Consultancy & Approx. 30 & male & 49 & $\begin{array}{l}\text { Bachelor in } \\
\text { engineering }\end{array}$ \\
\hline R16 & Consultancy & Approx. 50 & female & 36 & $\begin{array}{c}\text { Master in } \\
\text { management }\end{array}$ \\
\hline $\mathrm{R} 17$ & Manufacturing & Approx. 100 & female & 31 & $\begin{array}{c}\text { Master in } \\
\text { psychology }\end{array}$ \\
\hline $\mathrm{R} 18$ & Services & Approx. 80 & female & 26 & $\begin{array}{c}\text { Master in } \\
\text { psychology }\end{array}$ \\
\hline R19 & Trade & Approx. 150 & female & 28 & $\begin{array}{c}\text { Master in } \\
\text { management }\end{array}$ \\
\hline
\end{tabular}

In all, 19 semi-structured interviews were conducted. The longest interview lasted $85 \mathrm{~min}$. On average, the length of the interview was about an hour. Interviews were conducted in the Lithuanian language. All interviews were recorded digitally and later transcribed.

The interview guidelines comprised 11 sections of questions concerning each characteristic of sustainable HRM. The core questions are provided in Table 2. Certainly, in order to understand some of the information mentioned by the respondents better, additional questions were asked.

Table 2. The main interview questions.

\begin{tabular}{cc}
\hline Characteristics of Sustainable HRM & Main Interview Questions \\
\hline long-term orientation & $\begin{array}{c}\text { Could you describe the HRM strategy of your } \\
\text { organization? Please indicate the main values of your } \\
\text { organization. What factors of people management do } \\
\text { you consider from the long-term perspective? }\end{array}$ \\
care of employees & $\begin{array}{c}\text { Could you provide and describe the examples of } \\
\text { HRM practices showing that employees are } \\
\text { important to your organization? }\end{array}$ \\
care of environment & Could you provide and describe the examples of \\
HRM practices that address the \\
environmental issues?
\end{tabular}


Table 2. Cont.

\begin{tabular}{cc}
\hline Characteristics of Sustainable HRM & Main Interview Questions \\
\hline profitability & $\begin{array}{c}\text { What is the attitude of your organization to profit in } \\
\text { terms of HRM? }\end{array}$ \\
\hline employee participation and social dialogue & $\begin{array}{c}\text { Please indicate the possibilities the employees have to } \\
\text { participate in the organization's life }\end{array}$ \\
\hline external partnership & $\begin{array}{c}\text { Please describe how the employee development is } \\
\text { expressed and implemented is your organization }\end{array}$ \\
\hline flexibility & $\begin{array}{c}\text { How would you describe your organization's } \\
\text { relations with educational institutions? How would } \\
\text { you describe your organization's relations with } \\
\text { other stakeholders? }\end{array}$ \\
\hline compliance beyond labor regulations & $\begin{array}{c}\text { Please describe the forms of flexibility in terms of } \\
\text { work organization your employees have in } \\
\text { the organization }\end{array}$ \\
fairness and equality & $\begin{array}{c}\text { What do you do in terms of people management that } \\
\text { is on the top according to labor law? }\end{array}$ \\
\hline employee cooperation & $\begin{array}{c}\text { Could you describe the relations between your } \\
\text { employees? Could you describe the subordinates' } \\
\text { relations with line-managers? What are the employee } \\
\text { relations with the top-level managers? }\end{array}$ \\
\hline & $\begin{array}{c}\text { Please describe the approach of your organization } \\
\text { towards diverse workforce groups How do you deal } \\
\text { with equality issues in HRM? How do you deal with } \\
\text { fairness issues in terms of people management? }\end{array}$ \\
\hline
\end{tabular}

\subsection{Data Analysis}

The paper employed a theory-guided qualitative research [83]. In the study, the analysis was carried out by developing a theory-driven code system based on the characteristics of sustainable HRM. However, for data analysis and coding the adopted procedure was as follows [58,84]: (1) the researchers read all the interview transcripts to acquire an overall feeling; (2) all the transcripts were read multiple times and significant statements extracted along the way; (3) for each statement condensation was formulated; (4) condensations were clustered to sub-themes; (5) sub-themes were clustered into themes. Appendix A outlines an example of analysis and records the illustrative quotations, condensation, sub-themes and themes.

Next, the paper presents results focusing on sub-themes and themes through which sustainable HRM is expressed in people management in the organizations.

\section{Results}

This section addresses the practices through which the particular characteristics of sustainable HRM, namely long-term orientation, care of employees, care of environmental, profitability, employee participation and social dialogue, employee development, external partnership, flexibility, compliance beyond labor regulations, employee cooperation, fairness and equality, are expressed. The section is organized into 12 subsections, explaining in detail how organizations translate sustainable HRM into real business life by implementing various practices. Each section includes a table which outlines the sub-themes and themes of each characteristic.

\subsection{Care of Employees}

In general, the HR managers underlined the importance of employees as a key asset of an organization and as a critical resource for sustaining business. Overall, care of employees covers 
6 topics (themes) (Table 3) that relate to healthy employee; employee-friendly physical workspace; work-life balance; constructive stress management; attention to employee; adequate workload.

Table 3. Sub-themes and themes that relate to care of employees characteristics.

\begin{tabular}{|c|c|c|}
\hline Sub-Themes & Themes & Characteristic \\
\hline $\begin{array}{l}\text { promotion of healthier diet and physical activity; } \\
\text { promotion of employee health; encouragement to } \\
\text { give up harmful habits; illness prevention } \\
\text { measures; possibility to rest in spaces adapted for } \\
\text { this purpose; provision of health knowledge }\end{array}$ & healthy employee & \\
\hline ergonomic workplace; safety at work & $\begin{array}{l}\text { employee-friendly physical } \\
\text { workspace }\end{array}$ & \\
\hline $\begin{array}{l}\text { balancing the child-rearing and employment; } \\
\text { work and rest regimen taking into account the } \\
\text { personal aspects; spending time in corporate } \\
\text { events together with family members; } \\
\text { organization's care of the family members' health; } \\
\text { provision of knowledge on balancing work and } \\
\text { personal life; assistance to employees in dealing } \\
\text { with family issues }\end{array}$ & work-life balance & Care of employees \\
\hline $\begin{array}{l}\text { internal and external stress management training; } \\
\text { closer relationship between line-manager and } \\
\text { subordinate; help of psychologist }\end{array}$ & $\begin{array}{l}\text { constructive stress } \\
\text { management }\end{array}$ & \\
\hline $\begin{array}{l}\text { asking about how employees feel; awarding } \\
\text { employees; extending greetings on holidays }\end{array}$ & attention to employee & \\
\hline $\begin{array}{l}\text { regulation of workload; supporting the culture of } \\
\text { working in the workplace }\end{array}$ & adequate workload & \\
\hline
\end{tabular}

It seems that employee health is perceived as one of the top responsibilities of business and it is supported by a broad spectrum of practices such as promotion of healthier diet and physical activity, promotion of employee health, encouragement to give up harmful habits, etc. (Table 3). As HR managers described a huge amount of practices which are actually being carried out, only several illustrations are described below. Cafeterias which sell only healthy food, with the possibility to eat hot home-made food, or the possibility to bring food from home or activities with intentions to change or shape new nutrition habits are well established in organizations. Moreover, promotion of physical activity is expressed through two practice groups: practices within the organization and external initiatives, in which the employees of the organizations are encouraged to participate and indeed participate. Viewing through the prism of internal practices, the territory of the organization was effectively used to set up a football playing-field, the employees may take part in yoga classes and physical exercises and read the examples of physical exercises posted, for instance, in the elevator: "To production employees I have posted directly a few advertisements, when they use an elevator, they can read them and people do the exercises and say they are fun" (8R). In cooperation with partners, discounts are offered to attend sports clubs or costs of swimming pool or training are covered. In terms of external initiatives, participation in urban runs, bicycle marches or pedometer projects are encouraged and financially supported. Next, applying the illness prevention means, the demographic characteristics and nature of work are taken into account: "seeing that our company is $99 \%$ female, well, some time ago I got errr ... an idea, we discussed it with the girls and each year we arrange a breast checkup for them" (6R).

Employee-friendly physical workspace covers such subtopics as ergonomic workplace and safety at work. Although the following quotation reflects the perseverance of one organization in searching for better solutions in terms of working equipment, however it is more or less common in all companies: " $<\ldots>$ we make the effort to provide all employees simply with better working clothes, better working 
shoes. We also had problems—-they were not suitable for everyone. Errr ... it took us a few years to find the ones suitable for everyone" (8R).

The emphasis of HR managers on work-life balance as a way to care of employees is largely a response to criticism that business only seeks to exploit employees, for instance requiring to work longer hours than is agreed in the employment contract. The core message delivered by HR managers contradicts the public opinion because the organizations support work-life balance through a variety of practices provided in Table 2. The following quotation illustrates quite unusual practices related to help in solving family problems: "Recently, one male colleague called me and told he had a personal problem; he asked if we could talk about it and asked for an advice what to do-he did not know how to control his teenage daughter" (4R).

As sustainable HRM is aimed at reducing harm on different stakeholders, constructive stress management appeared to be a mega element in caring of employees, In general, culture that is not conducive to stress was revealed as the dominant one: "Nobody pats you on the back if you cause problems and make mistakes, but they are being solved and we try not to cause any fictitious stress" (12R). It seems that the number of organizations and employees taking part in internal or external stress management training is growing. In terms of stress reduction, HR managers raised the importance of closer relationship between the line manager and subordinate. Actually, the responsibility is divided and allocated to both parties: line manager: " $<\ldots>$ if the stress of the employees is visible to the manager, the latter should talk to them, ask how they are doing or something; perhaps the burden is too difficult for the person to carry" (9R), and subordinate: " $<\ldots>$ such environment that one would not be afraid to come to the supervisor to talk, if the workload is sincerely too heavy and perhaps an additional employee is necessary to help, perhaps an additional position" (9R). Several HR managers confirmed that a psychologist who helps in solving stress-related issues is a part of staff.

Next, it was quite common for HR managers to mention that they demonstrate attention to employees by asking about how they feel, awarding them and extending greetings on holidays. Election of the Best Employee or simply inquiring: " $<\ldots$ how a person feels and what we could do to make the situation better" (8R) leads to a situation that an employee is treated more as an end in itself, and not as a means for financial performance.

As regards adequate workload for employees, organizations employ the following two initiatives: regulation of workload and supporting the culture of working in the workplace. The first one covers the possibility for the employee to distribute the workload individually, for instance one day more working hours and next day less. The second one argues for not working at office or home after the agreed working time; for instance, employees are not allowed to send working emails during weekends.

Summing up, it could be stated that care of employees is expressed though a great variety of practices and such variety is mainly due to three reasons: dedicated finance, constructive approach to human resources and managerial solutions. Almost all practices of caring for employees are noted for permanence, which allows seeing a long-term benefit for the employee, organization and society. The largest spectrum of practices, simultaneously known for diversity, is revealed in the theme of a healthy employee (especially physical activity and healthy diet); however, this does not apply to the balance of work and personal life, which is essentially focused on the time dimension only, taking into account the children (family) and existence of personal needs (doctor, hairdresser). When assessing the nature of financial investments, it is noteworthy that the responsibility for health, friendly physical environment or showing attention to employees is not placed solely on employees; organizations allocate funds for this purpose and create the infrastructure. When assessing the managerial decisions of caring the human resources, the progress in constructive management of stress (starting with the attitude to stress and ending with the establishment of special positions) and workload (from the attitude to the 'working in the workplace' culture) are emphasized. 


\subsection{Care of Environment}

Before examining the practices through which the characteristic is implemented, it is relevant to highlight the three revealed aspects. Firstly, HR managers expressed disbelief that organizational efforts could help to save the environment: " $<\ldots>$ if we start from the environment, I would say that we would be able to make the least influence" (1R). Moreover, minimum amount of efforts and actions is recognized: "Well, I should think this is the minimum we could do in this field" (10R). Simultaneously, efforts are made to dissociate oneself and to leave the environmental protection on its own accord motivating this by the employee intelligence: "seeing that the company is sufficiently intellectual, the larger part of it somehow possesses the fundamentals of the green thinking and simultaneously the rudiments of the green behavior" (7R). In such a context, care of environment covers only one topic, namely environment-friendly solutions (Table 4).

Table 4. Sub-themes and theme that relate to care of environment characteristic.

\begin{tabular}{ccc}
\hline Sub-Themes & Theme & Characteristic \\
\hline environment-saving work logistics (for & & \\
instance use of bikes); saving and recycling of & & \\
paper; sorting of waste; saving of electricity; & environment-friendly & Care of environment \\
use of less plastic; trainings on environmental & solutions & \\
protection; campaign "Cleaning the & & \\
environment"; waste reduction initiatives & & \\
\hline
\end{tabular}

From Table 4 it is seen that solutions are mainly related to logistics, recycling, sorting, saving or training on environmental protection issues. However, it seems that practices are noted for the lack of heterogeneity, non-complexity, desultory and inconsistent approach to saving applying the consequence rather than cause-oriented solutions; however, preconditions associated with the consciousness of employees and application of organizational measures also exist. Organizations only implement practices that are associated with the saving of resources, work logistics, and environment cleanup works, while the environment saving indicators are not incorporated in the employee remuneration and performance assessment functions.

\subsection{Profitability}

Profitability is related to business effectiveness and covers one topic, namely profit as a prerequisite for survival (Table 5).

Table 5. Sub-themes and theme that relate to profitability characteristic.

\begin{tabular}{ccc}
\hline Sub-Themes & Theme & Characteristic \\
\hline $\begin{array}{c}\text { correlation between profit and nature and } \\
\text { amount of HRM initiatives }\end{array}$ & $\begin{array}{c}\text { profit as a prerequisite } \\
\text { for survival }\end{array}$ & Profitability \\
\hline
\end{tabular}

The correlation between profit and nature and amount of initiatives that are a sign of sustainable HRM was largely underlined. The following two quotations illustrate the correlation well: "let us say that profit is needed to ensure the welfare for the environment, both for the human being and for the employee in general" (2R) and "the profit earned or funds saved, irrespective of one case or another, go back to people. In one form or another. As salaries or some kind of bonuses. It nevertheless goes back to them" (6R).

\subsection{Long-Term Orientation}

Long-term orientation is largely based on acting according to the strategy and following values. However, the research revealed that only six organizations had a clear HRM strategy. 
Other organizations lacked strategic clarity, because there was either a "lifeless" human resource management strategy, or only certain strategic aspects regulated in different documents, or the strategy was non-existent altogether. In terms of values, 18 out of nineteen organizations had defined their values; one did not have the values identified, but it had the quotes of their director general dedicated to a calendar year and: " $<\ldots>$ the quotes are suitable for us as in a sense designating several of our values" (1R). Openness, honesty, transparency, reliability, continuous learning, customer focus, respect for oneself and others, fostering the creativity-promoting atmosphere, "four bigger cares"- these are the values followed by the organizations.

In such context, long-term orientation covers the topics related to long-lasting employment relations; fostering the sense of community; and being an attractive employer (Table 6).

Table 6. Sub-themes and themes that relate to long-term orientation characteristic.

\begin{tabular}{ccc}
\hline \multicolumn{1}{c}{ Sub-Themes } & Themes & Characteristic \\
\hline $\begin{array}{c}\text { considering the employee attitudes and expectations } \\
\text { during recruitment and performance appraisal; training } \\
\text { employees without experience; forecasting and regular } \\
\text { labor market analysis; internal career }\end{array}$ & $\begin{array}{c}\text { long-lasting } \\
\text { employment relations }\end{array}$ & \\
\hline $\begin{array}{c}\text { familiarization with the functions of other employees; } \\
\text { informal interaction of employees in corporate events; } \\
\text { the employee as the ambassador of the organization }\end{array}$ & $\begin{array}{c}\text { fostering the sense } \\
\text { of community }\end{array}$ & $\begin{array}{c}\text { Long-term } \\
\text { orientation }\end{array}$ \\
\hline $\begin{array}{c}\text { responsible attitude to employees; attractive conditions } \\
\text { of work; social initiatives }\end{array}$ & $\begin{array}{c}\text { being an } \\
\text { attractive employer }\end{array}$ & \\
\hline
\end{tabular}

As it was mentioned during interviews, organizations must consider the employee attitudes and expectations during recruitment (using various techniques) and performance appraisal seeing that the adjustment of employee and organization attitudes is the starting point for long-lasting employment relations. It was revealed that sometimes organizations employ workers even when there is no vacancy. The reasons lie in exceptional abilities of an employee or organization's preparation for employee turnover due to the impending retirement of an employee. Next, future-oriented employment relations are created through training employees without experience. In such case, employee commitment, namely normative commitment [85], is targeted striving to maintain the workforce. Further, forecasting and regular labor market analysis ensure at least one thing in terms of sustainability discourse - employees earn a salary that is equal or higher than that of competitors. However, it was highlighted that the full potential of forecasting and analysis is not used. Finally, possibilities for internal career also encourage employees to continue the employment relations.

The sense of community is created through such practices as familiarization with the functions of other employees, informal interaction of employees in corporate events as well as through the employee who is the ambassador of the organization in the events (Table 5). Below, several examples concerning familiarization with the peer functions are presented. For instance, in trainings, groups are formed from employees working in different divisions so that they perceive the specifics of each other's work. Furthermore, open-door events for employees are organized: "Well, let us say, according to division: " $<\ldots>$ They get to know the spectrum of services offered by our other division so that they could tell, for example, what a chambermaid's working day is like $<\ldots\rangle^{\prime \prime}$ (2R). Thus, organizations care about the employees having a common understanding of the functions carried out by the employee in another division and the way they are performed.

With regard to an attractive employer, organizations maintain a responsible attitude to employees, namely they not only declare, but take care of each employee: " $<\ldots>$ we declare that we care of each employee, of their welfare at work, and we live and breathe it" (3R). Attractive conditions of work in terms of refurbished physical working environment, the possibility for employees to develop themselves and aspects of remuneration were also stressed. Finally, such social initiatives enhance the 
employer's attractiveness: " $<\ldots>$ those social projects also attract the employees and people who particularly care about this—-the social responsibility" (9R).

In conclusion, the research emphasized striving towards aligning the values of the employee and the organization, which manifests through the overall matching and matching of specific values: approach to work, to improvement or social initiatives pursued by the organization. The striving to tune up the values is not of declarative nature, seeing that the attitudes and expectations of employees are identified in selection, appraisal and other human resource management functions. Building the future-oriented employment relations, the organizations anticipate the appearance of vacancies and possibilities to fill them up while applying different practices: hire a person even when there is no vacancy; invest in new competencies or simply adhere by the principal attitude that the employer is determined to continue the employment relations "beyond the retirement". Although the research mentioned market analysis, the use of its possibilities is narrow and fragmented, purely for remuneration and identification of required competencies. This allows stating that organizations have not yet encountered a serious challenge of the labor force shortage. Regardless of the availability of the options of internal career based on initiative, competence and interest, the flat structure of the majority of organizations examined makes pronounced changes of career not as plausible. Organizations pay attention to fostering a sense of community; however, most often it manifests through the informal interaction of employees or representation of the organization in events. Thoroughness requires a deeper "introduction" of employees in the organization's activities while striving that the employees are not simply aware of their colleagues' field of responsibility, but also identify their working functions with the mission of the organization. When creating the image of an attractive employer, the significance of the employee as the disseminator of information is particularly emphasized and organizations, therefore, tend to create more attractive conditions of work.

\subsection{Compliance beyond Labor Regulations}

Compliance beyond labor regulations covers just one topic, namely, additional, but not compulsory benefits for employees (Table 7).

Table 7. Sub-themes and theme that relate to compliance beyond labor regulations characteristic.

\begin{tabular}{ccc}
\hline Sub-Themes & Theme & Characteristic \\
\hline $\begin{array}{c}\text { financial support to employees; employee } \\
\text { insurance; additional days off; "the thirteenth } \\
\text { salary"; de jure recording of the working time } \\
\text { without de facto; use of the working time for } \\
\text { studies; annual holidays granted in advance }\end{array}$ & $\begin{array}{c}\text { additional, but not } \\
\text { compulsory benefits } \\
\text { for employees }\end{array}$ & $\begin{array}{c}\text { Compliance beyond } \\
\text { labor regulations }\end{array}$ \\
\hline
\end{tabular}

In Table 7 the provided practices serve as the illustrations of the mentioned benefits. Incidentally, the financial support is generally bigger than provided for by the law.

In general, qualitative research analysis shows that practices illustrating the presence of "more than imperatives" are not numerous or noted for diversity; however, the majority of them are characterized by the aspect of universality, i.e., they are applied to all employees without exception and do not represent a single occurrence. The majority of practices are associated with the expansion of social guarantees provided for by the Labour Code of the Republic of Lithuania or their adaptation for the benefit of the employee; on the other hand, there is a lack of practices that are not directly established in the Code, but the right to agree on them has been left to the discretion of the employer and employee. 


\subsection{Fairness and Equality}

Fairness and equality cover several topics that relate to diversity management; competence-based labor relations, labor relations based on willingness and interest to work; and transparency of labor relations (Table 8).

Table 8. Sub-themes and themes that relate to fairness and equality characteristic.

\begin{tabular}{ccc}
\hline Sub-Themes & Themes & Characteristic \\
\hline $\begin{array}{c}\text { gender balance; distribution of employees of } \\
\text { different ages and nationalities }\end{array}$ & diversity management & \\
\hline $\begin{array}{c}\text { employment based on the professional skills } \\
\text { rather than demographic characteristics }\end{array}$ & $\begin{array}{c}\text { competence-based } \\
\text { labor relations }\end{array}$ & Fairness and equality \\
\hline $\begin{array}{c}\text { employee interest in job more important than } \\
\text { demographic characteristics }\end{array}$ & $\begin{array}{c}\text { labor relations based on } \\
\text { willingness and interest } \\
\text { to work }\end{array}$ & \\
\hline $\begin{array}{c}\text { presentation of remuneration policy and its } \\
\text { explanation to all employees; fair payment for } \\
\text { work; equal opportunities to learn; equal } \\
\text { career opportunities }\end{array}$ & $\begin{array}{c}\text { transparency of } \\
\text { labor relations }\end{array}$ & \\
\hline
\end{tabular}

Speaking of diversity management, gender balance and distribution of employees of different ages and nationalities were stressed. It was observed in the research that organizations could be conditionally divided into two groups: male- or female-dominated organizations, and organizations where certain functions were carried out exclusively by males or females. In this case, the organizations experienced a gender balance challenge. It is interesting that sometimes organizations faced the issue when there were no women among the candidates to certain positions: " $<\ldots>$ OK, give me five women engineers. There are none. I don't even get any CVs" (13R). Referring to distribution of people of different ages, HR managers underlined that organizations were open to employees of various generations, moreover, pensioners were welcome. The same situation is with people of different nationalities, as they can be employed in all positions, just in some cases the Lithuanian language is a must.

The topic of competence-based labor relations is linked to the relevance of professional skills of employees (potential employees) rather than the demographic characteristics. In the organizations under research, manifestations of non-conformance culture were evident. In the first case, the specificity of sales business was not being taken into account: " $<\ldots>$ in business, where big sales must be made, you would see a lot of models like this $<\ldots>$ last week, on Thursday or Friday, there was an annual event, you would have seen almost all of them beauties in the hall, however my agency employs women from fifty to twenty-two. Both very plump and particularly thin" (6R). In the second case, customers negatively prejudiced against the gender of employees were not indulged: " $<\ldots$ $>$ let us take a simple $\langle\ldots>$-women want to go to women, men want to go to women. $\langle\ldots\rangle$, this would mean we have to hire only women, but actually, we have quite a number of men. $<\ldots$ $>$ Once again, we consider his professional qualities" (2R). Breaking the male and female profession stereotypes prevalent in the society, girls familiar with machinery were employed as managers of technical products. Moreover, a positive disposition about future prevailed: "We would gladly hire a lady mechanic, were such to appear" (3R), simultaneously expressing fears that no women were invited to the selection because of mismatch of experience and/or education.

It was mentioned that labor relations are based on willingness and interest to work. This leads to conclusion that an interest in a job is much more important than demographic characteristics, as shown in the following quotation: "We do not care; sometimes a person over fifty has a greater potential for work than another person aged 20 or 25 , who simply shows no interest in the job, in vacancy or position offered" (17R). 
Transparency of labor relations was proposed as a relevant indication of sustainable HRM implemented through presentation of remuneration policy and its explanation to all employees as well as through fair payment for work, equal opportunities to learn and equal career opportunities. Mostly, organizations follow this idea: " $<\ldots>$ in case of any problems, it has been decided on the highest level that employees are the first [to get paid], followed by managers, and the owners are the last" (4R).

In conclusion, diversity management, a focus on competencies of employees or future employees and transparency concerning vertical HRM practices were revealed as topics for diversity and equality characteristic expression in sustainable HRM.

\subsection{External Partnership}

External partnership covers several topics that relate to unity of business, society and studies; responsible interaction with local community; and responsible interaction with other stakeholders (Table 9).

Table 9. Sub-themes and themes that relate to external partnership characteristic.

\begin{tabular}{ccc}
\hline Sub-Themes & Themes & Characteristic \\
\hline $\begin{array}{c}\text { tours to companies for schoolchildren and } \\
\text { kindergartners; creation of pool of potential } \\
\text { employees; traineeships; employment of } \\
\begin{array}{c}\text { current students or graduates; involvement of } \\
\text { business partners in designing and } \\
\text { re-designing study programs and curriculum } \\
\text { and teaching }\end{array}\end{array}$ & $\begin{array}{c}\text { unity of business, society } \\
\text { and studies }\end{array}$ & \\
\hline $\begin{array}{c}\text { support for various cultural and social } \\
\text { initiatives }\end{array}$ & $\begin{array}{c}\text { responsible interaction } \\
\text { with local community }\end{array}$ & External partnership \\
\hline $\begin{array}{c}\text { correct information about former or current } \\
\text { employee; no engagement in deliberate } \\
\text { enticement of employees from } \\
\text { other organizations }\end{array}$ & $\begin{array}{c}\text { responsible interaction } \\
\text { with other stakeholders }\end{array}$ & \\
\hline
\end{tabular}

The answers of HR managers disclose a vast amount of practices as regards the unity of business, society and studies. Firstly, information about organizations and their activities is being spread to future employees through tours to schoolchildren and kindergartners: " $<\ldots>$ pupils come to our company and see what we have here and what is being done $\langle\ldots\rangle$ " (1R). Next, creation of a pool of potential employees is mainly achieved by excursions of students or their traineeships. It is observed that the attitude of organizations to traineeships is changing, emphasizing active traineeships of motivated students, which yields mutual benefits for the organization and the student: " $<\ldots>$ trainees come to me-okay, they can work; they make a plan of what they want to achieve within that month or three months and I want them to report every week on what they have achieved. Thus, you can see immediately if the person comes actually committed or is just fooling around" (6R). Further, employment of current students or graduates with no or short work experience also is an indication of sustainability in HRM. It seems that students get possibilities to deal with a huge amount of real business cases. In addition, business partners get involved in designing and re-designing study programs and curriculums, they also teach at universities. This ensures and extends the business changes to sustain access to the labor force.

Referring to responsible interaction with local community, the support for various cultural and social initiatives were mentioned. The answers of HR managers confirmed that ethical and philanthropic motives for supporting local communities are prevailing contrary to economical oriented practices. 
During interviews, responsible interaction with other stakeholders, namely with competing companies were revealed. The issue of interorganizational migration of employees was acknowledged. However, sustainability is reflected by providing to other organizations only the correct information about former or current employees. Moreover, organizations involved in the research did not engage in deliberate enticement of employees from others. Certainly, employees from competing companies are hired when they are interested in positions offered, however they are not encouraged to come to work, whereas the hiring takes place: " $<\ldots>$ by way of selection $<\ldots>$ " (3R) and " $<\ldots>$ on a value basis $<\ldots>$ " (3R).

In general, HRM practices as regards external partnership reflect both long-term and short-term orientations and are focused on having access to the labor market in order to sustain the business.

\subsection{Employee Cooperation}

Employee cooperation covers several topics that relate to the fostering of the culture of cooperation; fostering teamwork and shared responsibility; and well-designed relations of top managers, line managers and employees (Table 10).

Table 10. Sub-themes and themes that relate to employee cooperation characteristic.

\begin{tabular}{ccc}
\hline Sub-Themes & Themes & Characteristic \\
\hline $\begin{array}{c}\text { absence of the divide between personal } \\
\text { problems and working environment; } \\
\text { resolution of mutual disagreements of } \\
\text { employees; support for cooperation }\end{array}$ & the culture of cooperation & \\
\hline $\begin{array}{c}\text { disclosure of the interrelatedness of tasks; } \\
\text { showing that "unhealthy" competition } \\
\text { between employees is detrimental to the } \\
\text { entire organization }\end{array}$ & $\begin{array}{c}\text { fostering teamwork and } \\
\text { shared responsibility }\end{array}$ & Employee cooperation \\
\hline $\begin{array}{c}\text { direct interaction of managers and employees; } \\
\text { managers' showing interest in the personal } \\
\text { life of employee; open-door policy }\end{array}$ & $\begin{array}{c}\text { well-designed relations of } \\
\text { top managers, line } \\
\text { managers and employees }\end{array}$ & \\
\hline
\end{tabular}

The organizations create the culture of cooperation mainly through three practices: absence of the divide between personal problems and the working environment, resolution of mutual disagreements of employees, and support for cooperation. In the first case, the employees were encouraged to discuss their personal problems with colleagues at work as the following quotation clearly illustrates: "He comes to work and knows that he will also be able to talk about his problems $\langle\ldots\rangle$ " (1R). In the second case, disagreements between employees were being solved without any delay; moreover, several organizations mentioned that written and oral agreements on the solving of recurring contentions were drawn up and made. In the third case, the support for cooperation was encouraged by organizing the election of the most collegial employee.

Turning to teamwork and shared responsibility, it seems that the disclosure of the interrelatedness of tasks and showing that "unhealthy" competition between employees is detrimental to the entire organization are the main activities through which sustainability is embedded in HRM. The essence of interrelatedness of tasks is well described in the following quotation: " $<\ldots>$ if someone from sales fails to perform their work well, if they do not explain to the customer what data they need, the production cannot make the product without this data, or cannot make the product well or make it incorrectly; this means, the person from sales delivers the product and the customer tells them-what have you done, I will not pay you" (1R). In this case, internal communication and meetings are used to explain the added value of teamworking. With regard to the elimination of "unhealthy" competition between employees, organizations use not only verbal tools (meetings and explanations), but also different managerial tools, for example, instruction for managers to work within their region and prohibition to deal with customers outside their region. 
During interviews, it was quite common to talk about well-designed relations between top managers, line managers and employees. These relations refer to a range of practices that are applied in organizations, such as direct interaction of managers and employees, managers' showing interest in the personal life of employee, and open-door policy.

Direct interaction of managers and employees manifests in the manager regularly spending leisure time with employees. In such context, even in several organizations the top-level managers were ascribed the roles of mum and dad.

The interest of managers in personal life of employees is expressed through the knowledge of the division manager of personal worries and news of employees: " $<\ldots>$ chief technologists know how his son or daughter, or daughter in law, or grandchildren are doing, what is his health" (8R). Showing interest in the life of employees helps employing the practices for balancing work and personal life that are suitable for them and adopting value-creating decisions concerning the work organization, seeing that: "if the manager knows the employee personally, he will know them in work-related issues as well" (2R).

The open-door policy is understood dually, both literally and figuratively. The practice that illustrates the figurative sense manifests through the possibility of an open, direct contact of the employee with the manager, without observing the receiving hours; furthermore, the manager admits any employee for a discussion. The literal sense is reflected by the absence of doors and plates with the receiving hours as well as opened doors to all offices, unless a meeting is taking place.

In general, it seems that fostering of cooperation culture is treated with high relevance in most organizations. Additionally, added value of cooperation is perceived by the top level managers modelling cooperation through their own behavior.

\subsection{Employee Participation and Social Dialogue}

HRM managers referred to employee participation and social dialogue as relevant tools for embedding sustainability in HRM, which cover several topics that relate to general participation accessibility; organizational means for promoting employee participation; motivation of employees to participate; participation in making decisions on different issues (Table 11).

Table 11. Sub-themes and themes that relate to employee participation and social dialogue characteristic.

\begin{tabular}{|c|c|c|}
\hline Sub-Themes & Themes & Characteristic \\
\hline $\begin{array}{l}\text { provision of proposals to managers } \\
\text { tête-à-tête; provision of proposals to the } \\
\text { personnel manager tête-à-tête; existence of a } \\
\text { special positions in charge of employee } \\
\text { inclusion and social dialogue; meetings of } \\
\text { divisions; meetings of all employees; } \\
\text { proposal boxes; generation of proposals } \\
\text { during special trainings, and complex } \\
\text { employee opinion surveys }\end{array}$ & $\begin{array}{l}\text { general participation } \\
\text { accessibility }\end{array}$ & \\
\hline $\begin{array}{l}\text { special trainings; personal encouragement of } \\
\text { the top-level manager; the duty of } \\
\text { participation embedded in official documents }\end{array}$ & $\begin{array}{l}\text { organizational means } \\
\text { for promoting } \\
\text { employee participation }\end{array}$ & $\begin{array}{l}\text { Employee participation } \\
\text { and social dialogue }\end{array}$ \\
\hline $\begin{array}{l}\text { financial incentives; public recognition of } \\
\text { individual's authorship or acknowledgment }\end{array}$ & $\begin{array}{l}\text { motivation of employees } \\
\text { to participate }\end{array}$ & \\
\hline $\begin{array}{l}\text { employees are involved in solving both } \\
\text { work-relate and organizational issues }\end{array}$ & $\begin{array}{l}\text { participation in making } \\
\text { decisions on different issues }\end{array}$ & \\
\hline
\end{tabular}

Concerning general participation accessibility, a vast range of forms for employee participation was revealed (Table 11). To gain a benefit, organizations are fostering an open, two-way communication 
with possibility for confidentiality. In most organizations, information technologies are used for valuable participation.

It seems that business admits that employee participation should be fostered by organizations themselves. Consistently with this view, several organizational means were mentioned for activating employee participation, for instance, special trainings, personal encouragement of the top-level manager and the duty of participation embedded in official documents.

Another aspect related to the fostering of participation relies on employee motivation. Organizations mainly use a mix of financial and non-financial forms of motivation in terms of financial incentives, public recognition of individual's authorship, or acknowledgment.

Referring to participation in making decisions on different issues, employees are involved in solving both work-relate and organizational issues. For illustration, this example could be used: during the economic crisis, they had to decide on reducing the staff or salaries: "And each division had to make an internal decision - to reduce the number of employees or everybody gets their salary reduced so that everybody could stay" (1R).

Generally speaking, from interviews it is obvious, that fostering participation and social dialogue brings added value for organizations in terms of new business ideas, and improvement of technical aspects, working conditions, and product or service quality. The following quotation by a HR manager illustrates well the added value of employee participation: "And actually all our services, 2-3 every year, new services-they all appear thanks to employees" (1R). This leads to the conclusion that fostering of employee participation in terms of organizational tools, motivation or application of various proposal forms add value for sustaining the people and the organization itself.

\subsection{Employee Development}

Employee development covers several topics that relate to the use of various forms for employee development, transfer of experience, and employability (Table 12).

Table 12. Sub-themes and themes that relate to employee development characteristic.

\begin{tabular}{ccc}
\hline Sub-Themes & Themes & Characteristic \\
\hline $\begin{array}{c}\text { fairs, internships, seminars and internal } \\
\text { training using information } \\
\text { technologies platforms }\end{array}$ & $\begin{array}{c}\text { the use of various forms for } \\
\text { employee development }\end{array}$ & \\
\hline $\begin{array}{c}\text { introductory training of new employees; } \\
\text { financial reward for transferring } \\
\text { experience; mentorship }\end{array}$ & transfer of experience & Employee development \\
\hline $\begin{array}{c}\text { acquisition of a formal document; making } \\
\text { connections; working experience in a } \\
\text { specific organization; creation of } \\
\text { possibilities for employee }\end{array}$ & employability & \\
$\begin{array}{c}\text { self-development despite the threat for } \\
\text { the organization to lose intellectual capital }\end{array}$ & & \\
\hline
\end{tabular}

In general, HR managers referred to employee development as one of the main features of a sustainable organization. Development becomes even more important in the light of Industry 4.0 as new skills and competences, which do not exist now will be in demand quite soon. An obvious need for employees of broader profile was identified: "The further the more we need them rather than specialists of a narrow specialization" (4R). The time dimension determines the changes of the competences associated with the dealing with customers: "Ten years ago, the customer could be approached with different competencies than needed now" (12R), while the changing environment demands for the organizations to watch: " $<\ldots$ > whether the intellectual resources of the organization are being constantly updated" (14R). 
Concerning the use of various forms for employee development, the combination of internal and external training seems to be a common practice. Thus, fairs, internships, seminars and internal training using information technologies platforms were mostly mentioned.

Referring to the transfer of experience, HR managers identified the introductory training of new employees, financial reward for transferring experience and mentorship. The transfer of experience becomes possible when working in the same projects and showing an example to other employees or involving them into certain activities. Teamwork allows observing, analyzing and learning from each other. Participation of employees with experience and those who do not have it in joint trainings and documentation of the experience help attaining the same objective.

Turning to employability, several practices were disclosed, namely: acquisition of a formal document; making connections; working experience in a specific organization; and creation of possibilities for employee self-development despite the threat for the organization to lose intellectual capital.

Acquisition of a formal document refers to the organization creating the conditions for the employees to take part in trainings the successful completion of which is corroborated by a certificate affecting the attractiveness of the employee in the labor market: "trainings are necessary both for the company and the person, making him/her more qualified on the labor market and making it better for them to sell themselves" (1R). Furthermore, the value of the document certifying one's qualification is enhanced by enabling the employees to present themselves in the labor market, i.e., when conducting seminars, and to reach out to potential future employers.

Working experience in an organization reveals itself through the fact that work in the organization creates the preconditions for the employee to pass the test and gain employment in another organization: " $<\ldots>$ there was one employee, now she works in Switzerland; when she was applying for a job with a Swiss company, there was an interview and the only examination in writing about social responsibility" (5R). Moreover, a situation is possible when employees "grow" in an organization: "The are cases when people grow up, they have worked for many years and start yearning for something different. So we just feel glad for them and wish them luck elsewhere" (3R).

Creating the possibilities for the employee self-development regardless of the threat to the organization to lose the intellectual capital manifests in employee trainings emphasizing that: "Whatever you take with you is yours. You cannot save the program on the server and leave empty-handed. That is not the case" (5R).

In summary, employee development is seen as an important aspect of sustainable HRM and organizations take quite a lot of responsibility for future competence development.

\subsection{Flexibility}

Overall, the need for flexibility in terms of both employee and organization was underlined. It seems that flexibility of sustainable HRM covers the topics that relate to responsible management of employee time; employee internal mobility; and employee substitution system (Table 13).

Table 13. Sub-themes and themes that relate to flexibility characteristic.

\begin{tabular}{ccc}
\hline Sub-Themes & Themes & Characteristic \\
\hline $\begin{array}{c}\text { flexible work schedule, the possibility to work } \\
\text { from home; responsible planning of vacations }\end{array}$ & $\begin{array}{c}\text { responsible management of } \\
\text { employee time }\end{array}$ & \\
\hline $\begin{array}{c}\text { temporary workplace change; } \\
\text { employee rotation }\end{array}$ & employee internal mobility & Flexibility \\
\hline $\begin{array}{c}\text { different types of substitutions; learning one } \\
\text { from another; formal regulation of } \\
\text { employee substitution }\end{array}$ & employee substitution system & \\
\hline
\end{tabular}


Responsible management of employees' time includes several subtopics. The starting point is flexible work schedule, however due to specifics of industries in many cases certain groups of employees have the priority to arrange flexible working hours, for instance those who have children under 16. Additionally, the possibility to work from home allows the employee to balance work and personal life better. Meanwhile, responsible planning of vacations is based on two conditions: vacations are planned considering the possibility for the employees to substitute for each other and the employees are also asked to take vacations whenever the workload is lesser. Such planning eliminates higher workload for employees before or after vacations.

Employee internal mobility covers temporary workplace change and employee rotation. In the first case, the organization creates the possibilities for employees to work in another factory when their workplace is under reconstruction. Employee rotation encompasses the change of the working functions both seeking to confer novelty to the working activity: "they rotate them, change jobs after a few years, because it becomes boring for the person when they keep doing the same for two or may be more years" (9R), and emphasizing the importance for the employee to gain new experience: " $<\ldots$ $>$ the divisions, which can, simply rotate jobs. This means new experience and they learn different things $<\ldots>$ " (9R).

Employee substitution system covers three subtopics: different types of substitutions, learning one from another and formal regulation of employee substitution. Substitution of co-workers having the same position, or belonging to the same or different departments enables employees to enrich their work and to broaden their understanding about the company's activities. Learning one from another is strongly encouraged by real examples of internal career or better employability in general. In several organizations, formal regulation of employee substitution is expressed though the prepared substation and career map: " $<\ldots>$ so that you know which employee can substitute for the other in extra cases and what competencies they need" (3R).

However, it should be admitted that practices as regards the flexibility are not widely and deeply implemented. For instance, in many organizations, the possibility to work from home is related to additional circumstances. Moreover, HR managers underlined that the rotation possibilities we not thoroughly used whereas substitutions were invoked to solve the issues of work organization rather than competence development; furthermore, formalization of substitutions that would allow for more effective management of the human resources was lacking.

\subsection{The Outline of General Research Results}

The findings of the qualitative research allow stating that in the surveyed organizations, expression of sustainable HRM characteristics through different practices was determined. It is important to stress that there is a potential of the attitude to progress towards sustainability because the care of employees and environment are acknowledged as outcomes of organizational activities of equal significance alongside the financial ones. Nonetheless, the expression of sustainable HRM characteristics was not noted for heterogeneity. Although the corporate attitude is appropriate, real activities that encompass the equivalence of economic, social and environmental triad are lacking. It is likely that the attitudes and feelings will transform into concrete activities.

Following the research findings, the sustainable HRM characteristics could be divided into three groups by the abundance and variety of practices revealed: explicitly expressed, moderately expressed and weakly expressed characteristics (Table 14). 
Table 14. The expression of sustainable HRM characteristics.

\begin{tabular}{cc}
\hline Sustainable HRM characteristics & Level \\
\hline $\begin{array}{c}\text { Care of employees, profitability, external partnership, } \\
\text { fairness and equality, and employee development }\end{array}$ & explicitly expressed characteristics \\
\hline $\begin{array}{c}\text { Long-term orientation, flexibility, employee } \\
\text { participation and social dialogue, and } \\
\text { employee cooperation }\end{array}$ & moderately expressed \\
\hline $\begin{array}{c}\text { Care of environment and compliance beyond } \\
\text { labor regulations }\end{array}$ & weakly expressed characteristics \\
\hline
\end{tabular}

At it is seen from Table 14, care of employees, profitability, external partnership, fairness and equality, and employee development were revealed as characteristics of sustainable HRM expressed the most explicitly through HRM activities. Long-term orientation, flexibility, employee participation and social dialogue, and employee cooperation seem to be moderately expressed. Meanwhile, care of environment and compliance beyond labor regulations are the characteristics that were expressed the least.

\section{Discussion}

The purpose of the paper was to increase the knowledge of sustainable HRM by revealing the practices through which the 11 characteristics of sustainable HRM are expressed in real (virtual) people management in organizations. In doing this, qualitative data were collected from Lithuanian organizations using semi-structured interviews with $19 \mathrm{HR}$ managers. As it was concluded by Diaz-Carrion et al. [53], it seems that institutional context matter in how sustainable HRM is translated into practice. Further, the discussion is developed concerning results as regards each of the characteristics, namely long-term orientation, care of employees, care of environmental, profitability, employee participation and social dialogue, employee development, external partnership, flexibility, compliance beyond labor regulations, employee cooperation, fairness and equality.

The research results concerning the care of employees support the findings of Ehnert [16] when website analysis revealed that ergonomic working conditions, keeping fit, reducing and preventing stress, and work-life balance were the activities related to sustainable HRM in 50 organizations, members of the European World Business Council for Sustainable Development (WBCSD). From the literature review, the need to implement practices that foster mental and psychical health of employees is evident [24,65-67]. It seems that not only Finnish companies where managers and employees have longer and better experience with sustainability-related thinking [32], but also Lithuanian organizations respond to the mentioned call by implementing practices, which address the health dimension of employee well-being [10]. Actually, the vast number of different practices to stating that the results are in line with the empirical conclusion of Guerci and Pedrini [44] that managers perceive health and safety processes in organizations as the most important for sustainability-driven changes. Further, the results support the idea of Diaz-Carrion et al. [31] that work-life balance becomes especially relevant in terms of sustainable HRM.

Turning to the care of environment, research results correspond well to the evolution of the concept of sustainable HRM. As it is known from previous literature, at the beginning, ecological outcomes were not included in the sustainable HRM frameworks [16,20,21] or practice-based models [16]. Only recently, scholars in the field of sustainable HRM have started admitting that the multiple bottom line orientation means not only maintaining an efficient organization and treating human resources in a socially responsible manner, but also integrating ecological goals [23,27]. However, it seems that managers need time to fully accept that environmental issues are part not only of green HRM [47-49], but also of sustainable HRM. Järlström et al. [32] found only one quotation, regarding travel cost reducing. HR managers in Lithuanian organizations provided more examples of 
environmentally-friendly solutions, however these solutions are not fully integrated in vertical HRM practices like selection or compensation.

In terms of profitability, the research results convey the message that profit is important to other initiatives of sustainable HRM. Thus, the hard version of HRM that stresses financial outcomes is integrated in sustainable HRM [32]. Moreover, findings fit well to theoretical sustainable HRM frameworks where economic outcomes are treated equally with social, individual [16] and more recently with ecological results [27].

Concerning long-term orientation, the research results only partially fit the findings of Järlström et al. [32] where the need for holistic thinking in sustainable HRM was revealed. Organizations in Lithuania still lack a clear HRM strategy, although practices are mainly based on identified values. Concerning particular initiatives, support was found for findings of Ehnert [16] as sustained employment relations and organization's reputation are treated by the Lithuanian HR managers as an integral part of sustainable HRM. Correspondingly, the results are in line with the findings of Zaugg et al. [20] in terms of attractiveness of organization and investments in various techniques striving to recruit the ideal candidates. Although planning of human resource quality and quantity was mentioned by the HR managers, it seems that managers in Finnish companies use planning more systematically in the best possible way [32].

It is acknowledged that acting according to the law is a necessary, but an insufficient precondition for sustainable HRM [34]. As noted by Järlström et al. [32], obeying the requirements does not necessary signal that an organization is sustainable. Transferring this to the HRM context, doing more for the employees than is required by the Labor Code represents a stronger commitment to sustainability. Thus, the research results are in line with study conducted in Finland [32], however practices differ in their nature: in Finland, a collective agreement is seen as an important element of sustainable HRM, whereas HR managers in Lithuania mentioned more additional benefits in terms of financial reward or support for work-family balance. This is a corollary of the fact that in Lithuania trade unions do not have strong traditions.

The research results demonstrated that HRM practices in terms of fairness and equality are clearly expressed in Lithuanian organizations. Diversity management, referring for example to the employment of people of different ages, nationalities and gender, was also revealed in previous studies [16,20,31,32]. As in the case of Finland, HRM managers in Lithuanian companies argued for equal treatment of all employees by placing high importance on such sensitive things, as explanation of remuneration policy. Actually, the reward policy does not discriminate by gender or type of contract was revealed in study of Diaz-Carrion et al. [31] as the most sustainable practices.

External partnership as a core characteristic of sustainable HRM has been largely underlined by the German school [36] providing a causal explanation for mutual exchange between the organization and its environments. Later, the idea was elaborated in writings of Ehnert $[16,23]$ arguing that creating mutual relationships and partnership with the education system, corporate partners and NGO's can support business in solving several HRM challenges, firstly attracting and maintaining skilled employees. Thus, the research results from Lithuanian organizations are line with the previously mentioned theoretical insights and slightly contradict the empirical findings of Zaugg et al. [20] where cooperation with education institutions was not mentioned as a systematic tool of sustainable HRM.

It should be admitted that employee cooperation is not a characteristic of sustainable HRM well disclosed in the literature. Brown and Shields [73] argue that based on the tournament theory competing employees have a strong intention to undermine their co-workers' activities. In doing this, the employees can improve their own performance, but the overall performance can be reduced. Thus, employee cooperation is much more beneficial than competition in terms of economic and social outcomes. For instance, Hirsig et al. [86] underline that cooperation increases overall job satisfaction, fosters improved quality and productivity and lowers the risk of labor disputes. From research results it seems that Lithuanian organizations should pay more attention to employee cooperation as practices as regards cooperation was moderately expressed. 
Turning to employee participation and social dialogue, the research results revealed that organizations foster participation and as a result reap benefits in terms of new business ideas. Joensson [87] underlines that employee participation may apply to decisions about very different issues acknowledging two types of issues: work-related (or "proximal issues") and organizational issues ("distal issues"). "Proximal issues" are related to immediate conditions for employees to perform the job, for instance organising work tasks. In the meantime, "distal issues" are related to the employees' distal organizational environment, such as decisions on organizational strategy or financial decisions. It seems that employees in Lithuanian organizations target both kind of issues, however more attention is "proximal issues". Such research results match the findings of Järlström et al. [32], as in the Finish case, the employee participation in work-related decision making was found to be a relevant element for securing sustainability.

The research results in terms of employee development support the findings of Ehnert [16] when investing in employees or talent and their knowledge was identified as an important objective of sustainable HRM. Practice-based model for the representation of sustainability and HRM link provided by Ehnert [16] found that human resource training and development, life-long learning, and employability presented as highly important activities. Further, research results fit to Hoeppe's [76] insights from a German bank, where competencies and qualifications of employees were treated as highly important. Additionally, employability stressed by the Lithuanian HR managers is a core objective of sustainable HRM model provided by Zaugg et al. [20].

The research results correspond to the findings of Järlström et al. [32] arguing for the demand for flexibility in terms of employee needs and simultaneously acknowledging that this is really challenging for business. It seems that Lithuanian organizations use the flexibility more in terms of business needs. This assumption applies more to employees rotation and substitution, whereas flexible working time, as in the case of the German bank [76], is applied with a more employee-centered approach. Flexible working hours, as noted by Zaugg et al. [20], is the most prevalent solution as regards flexibility and this is true for the Lithuanian case also. Surprisingly, such forms of flexibility as job-sharing or sabbaticals [20] were not revealed. This could be partially explained by the specific of industries the research was carried in.

\section{Conclusions}

Following the approach that external and internal challenges require to re-think the mainstream HRM, the paper introduces sustainable HRM. Irrespective of the short history of sustainability in HRM debates, sustainable HRM represents a new approach to people management by recognizing multiple, potentially contradictory economic, ecological and social goals and by admitting complex interrelations between the HRM systems and their internal and external environments with emphasis on relationships, which allow the long-term reproduction of resources and control externalities.

Certainly, the previous research in sustainable HRM has broadened the understanding about the meaning of the emerging construct and its main features, which differentiate if from the mainstream HRM. Drawing on the previous works, sustainable HRM can be characterized by the following 11 characteristics: long-term orientation, care of employees, care of environment, profitability, employee participation and social dialogue, employee development, external partnership, flexibility, compliance beyond labor regulations, employee cooperation, and fairness and equality. Although different scholars made several attempts to describe the mentioned characteristics, the lack of empirical evidence as regards the practical manifestation of characteristics in concrete business organizations is obvious. The paper aimed at closing this gap by examining how the theoretical concept of sustainable HRM is being translated into business practice. Thus, the purpose of the paper was to reveal the practices through which the 11 characteristics of sustainable HRM are expressed in real (virtual) people management in organizations. In doing this, the qualitative data collected from $19 \mathrm{HR}$ managers working in Lithuanian organizations which are the members of the Lithuanian Association 
of Responsible Business or declare commitment to sustainability providing sustainability reporting were used.

Turning to the expression of characteristics, the research revealed the variety of practices with a varying degree of maturity. The practices covered by particular characteristics are provided further. Care of employees covers the HRM practices that relate to healthy employees, employee-friendly physical workspace, work-life balance, constructive stress management, attention to employee, and adequate workload. Care of environment covers only one topic, namely environment-friendly solutions. Profitability is related to business effectiveness and includes one topic: profit as a prerequisite for survival. Long-term orientation encompasses the topics related to long-lasting labor relations, fostering the sense of community, and being an attractive employer. Compliance beyond labor regulations covers just one topic, namely additional and not compulsory benefits for employees. Fairness and equality includes several topics that relate to diversity management, competence-based labor relations, labor relations based on willingness and an interest to work, and transparency of labor relations. External partnership covers the topics that relate to unity of business, society and studies, responsible interaction with local community, and responsible interaction with other stakeholders. Employee cooperation includes the topics that are associated with the fostering of the cooperation culture, fostering teamwork and shared responsibility, and well-designed relations of top managers, line managers and employees. Employee participation and social dialogue covers several topics that relate to the general participation, organizational means for promoting employee participation, motivation of employees to participate, and participation in making decisions on different issues. Employee development encompasses the topics that relate to the use of various forms of employee development, transfer of experience, and employability. Flexibility covers the topics that relate to responsible management of employee time, employee internal mobility, and employee substitution system.

The paper provides several practical implications. The revealed practices through which sustainable HRM is expressed in organizations could be treated by practicians as an "example list" what to do in order to start or to strengthen the sustainability implementation in people management. Certainly, a more opened discussion on what sustainable HRM means in each particular organization is needed; however, current research gives some insights. Further, as the revealed practices still lack maturity, the avenue for improvement of these practices is opened recognizing the need to follow a holistic approach by acknowledging potentially contradictory economic, ecological and social goals and by admitting complex interrelations between HRM systems and their environments, both internal and external. Next, the practical contribution is the observation that the ways the HR managers perceive sustainability in people management are highly relevant seeing that the HR managers play a critical role in legitimating activities, allocating resources and, in general, fostering the spirit of sustainability in an organization. Finally, the disclosure of practices of sustainable HRM can encourage businesses to accept contemporary changes as sustainable HRM has the potential to support the transformation of business towards sustainability.

The research has certain limitations that suggest directions for future research. The first one relates to the target group, namely HR managers. It might be plausible that the position has affected their answers. In order to acquire a better view, interviews with line managers and survey of employees could be appropriate for the future. Further, although national context is relevant when explaining the expression of the sustainable HRM, this creates difficulties in generalizing data. Based on findings in Finland [32], it could be stated that the results can be generalized to most European countries. However, based on findings of Diaz-Carrion et al. [31,53] there is the difference among countries in Europe (Germany, Spain, Sweden and the United Kingdom) with regard to sustainable HRM practices. This leads to conclusion that further research is needed. Finally, the field of sustainable HRM can benefit from further discussion on characteristics and practices that might constitute a checklist for sustainability in people management. 
Author Contributions: The authors Ž.S. and A.S. contributed equally to this paper.

Funding: This research received no external funding.

Conflicts of Interest: The authors declare no conflict of interest.

\section{Appendix A. The Example of Illustrative Quotations, Condensation, Sub-Theme and Theme}

Table A1. The example of quotations, condensation and sub-theme of healthy employee.

\begin{tabular}{|c|c|c|c|}
\hline Illustrative Quotations & Condensation & Sub-Theme & Theme \\
\hline $\begin{array}{l}\text { "The possibility is provided to eat hot, } \\
\text { healthy food that had been just cooked. } \\
\text { It has been agreed with the canteen } \\
\text { operator that food should be healthy } \\
\text { and not just delicious" }\end{array}$ & $\begin{array}{l}\text { Possibility to eat fresh and } \\
\text { healthy meals in the canteen }\end{array}$ & & \\
\hline
\end{tabular}

"The restaurant fosters a somewhat new philosophy about food, it is Čibus, Sanitas per Čibus, this means health Healthy lunch through food. $<\ldots>$ The same healthy lunch"

\begin{tabular}{|c|c|c|c|}
\hline $\begin{array}{l}\text { "The canteen works only at daytime, } \\
\text { but they can access the premises around } \\
\text { the clock and heat up the food in the } \\
\text { microwave by themselves" }\end{array}$ & $\begin{array}{l}\text { Possibility to heat the food } \\
\text { that the employees bring }\end{array}$ & & \\
\hline $\begin{array}{l}\text { "We offer the possibility to eat at the } \\
\text { workplace, there are microwaves, } \\
\text { crockery, a coffee maker }<\ldots>\text { " }\end{array}$ & & $\begin{array}{l}\text { Promotion of } \\
\text { healthier diet }\end{array}$ & $\begin{array}{l}\text { Healthy } \\
\text { employee }\end{array}$ \\
\hline \multicolumn{4}{|l|}{$\begin{array}{l}\text { "And we also have kitchenettes for } \\
\text { employees, so that they could heat up } \\
\text { the food }<\ldots>\text { " }\end{array}$} \\
\hline \multicolumn{4}{|l|}{$\begin{array}{l}\text { "< }<\text { > on the second floor, we have a } \\
\text { recreation zone, a sort of canteen" }\end{array}$} \\
\hline $\begin{array}{l}\text { "We try to teach the people not to eat } \\
\text { much sugar and salt" }\end{array}$ & $\begin{array}{l}\text { Encouragement to forgo } \\
\text { sugar and salt }\end{array}$ & & \\
\hline $\begin{array}{l}"<\ldots>\text { I just brought a cocktail maker } \\
\text { and left it at work so that we could } \\
\text { purée the fruit, or we treat each other" }\end{array}$ & $\begin{array}{l}\text { Possibility to make } \\
\text { fruit cocktails }\end{array}$ & & \\
\hline $\begin{array}{l}\text { "We allow the employees to purchase } \\
\text { the good food products at our price, in } \\
\text { that sense, or to use some kind of a } \\
\text { procedure, or to purchase our } \\
\text { professional cosmetics that they could } \\
\text { never buy anywhere for their own use" }\end{array}$ & $\begin{array}{l}\text { Possibility for the employee } \\
\text { to purchase better food } \\
\text { products at the cost paid by } \\
\text { the organization or } \\
\text { cosmetics that are not } \\
\text { offered for sales }\end{array}$ & & \\
\hline
\end{tabular}

\section{References}

1. Ulrich, D.; Dulebohn, J.H. Are we there yet? What's next for HR? Hum. Resour. Manag. Rev. 2015, 25, $188-204$. [CrossRef]

2. Beer, M.; Boselie, P.; Brewster, C. Back to the future: Implications for the field of HRM of the multistakeholder perspective proposed 30 years ago. Hum. Resour. Manag. 2015, 54, 427-438. [CrossRef]

3. Cleveland, J.N.; Byrne, Z.S.; Cavanagh, T.M. The future of HR is RH: Respect for humanity at work. Hum. Resour. Manag. Rev 2015, 25, 146-161. [CrossRef]

4. Marchington, M. Human resource management (HRM): Too busy looking up to see where it is going longer term? Hum. Resour. Manag. Rev. 2015, 25, 176-187. [CrossRef]

5. Boxall, P.; Guthrie, J.P.; Paauwe, J. Editorial introduction: Progressing our understanding of the mediating variables linking HRM, employee well-being and organisational performance. Hum. Resour. Manag. J. 2016, 26, 103-111. [CrossRef] 
6. Combs, J.; Liu, Y.; Hall, A.; Ketchen, D. How much do high-performance work practices matter? A meta-analysis of their effects on organizational performance. Personnel Psychol. 2006, 59, 501-528. [CrossRef]

7. Guest, D. Human resource management, corporate performance and employee wellbeing: Building the worker into HRM. J. Indust. Relat. 2002, 44, 335-358. [CrossRef]

8. Huselid, M.A. The impact of human resource management practices on turnover, productivity, and corporate financial performance. Acad. Manag. J. 1995, 38, 635-672.

9. Jiang, K.; Lepak, D.P.; Hu, J.; Baer, J.C. How does human resource management influence organizational outcomes? A meta-analytic investigation of mediating mechanisms. Acad. Manag. J. 2012, 55, 1264-1294. [CrossRef]

10. Van De Voorde, K.; Paauwe, J.; Van Veldhoven, M. Employee well-being and the HRM-organizational performance relationship: A review of quantitative studies. Int.l J. Manag. Rev. 2012, 14, 391-407. [CrossRef]

11. Guest, D.E. Human resource management and employee well-being: Towards a new analytic framework. Hum. Resour. Manag. J. 2017, 27, 22-38. [CrossRef]

12. Ehnert, I.; Harry, W.; Zink, K.J. Sustainability and HRM. An introduction to the field. In Sustainability and Human Resource Management: Developing Sustainable Business Organizations; Ehnert, I., Harry, W., Zink, K.J., Eds.; Springer: Berlin/Heidelberg, Germany, 2014; pp. 3-32, ISBN 978-3-642-37524-8.

13. Ehnert, I.; Harry, W. Recent developments and future prospects on sustainable human resource management: Introduction to the special issue. Manag. Rev. 2012, 23, 221-238. [CrossRef]

14. Pfeffer, J. Building sustainable organizations: The human factor. Acad. Manag. Perspect. 2010, 24, 34-45.

15. AON Hewitt. 2017 Trends in Global Employee Engagement. Available online: http:/ / www.modernsurvey. com/wp-content/uploads/2017/04/2017-Trends-in-Global-Employee-Engagement.pdf (accessed on 10 October 2018).

16. Ehnert, I. Sustainable Human Resource Management. A Conceptual and Exploratory Analysis from a Paradox Perspective; Physica-Verlag: Berlin/Heidelberg, Germany, 2009; ISBN 978-3-7908-2188-8.

17. Mariappanadar, S. The harm indicators of negative externality of efficiency focused organizational practices. Int. J. Soc. Econ. 2012, 39, 209-220. [CrossRef]

18. Mariappanadar, S. Harm of efficiency oriented HRM practices on stakeholders: An ethical issue for sustainability. Soc. Bus. Rev. 2012, 7, 168-184. [CrossRef]

19. Mariappanadar, S. Health harm of work from the sustainable HRM perspective: Scale development and validation. Int. J. Manpower 2016, 37, 924-944. [CrossRef]

20. Zaugg, R.J.; Blum, A.; Thom, N. Sustainability in Human Resource Management. Evaluation Report. Survey in European Companies and Institutions. Arbeitsbericht des Instituts für Organisation und Personal der Universität Bern und des eidgenössischen Personalamtes; IOP Press: Berne, Switzerland, 2001; ISBN 3-906471-48-9.

21. Zaugg, R.J. Sustainable HR Management: New Perspectives and Empirical Explanations; Gabler: Wiesbaden, Germany, 2009; ISBN 978-3-8349-2103-1.

22. Clarke, M. Sustainable HRM: A New Approach to People Management; Tilde University Press: Prahran, Australia, 2011; ISBN 978-0-7346-1101-7.

23. Ehnert, I. Paradox as a lens for theorizing sustainable HRM. In Sustainability and Human Resource Management:Developing Sustainable Business Organizations; Ehnert, I., Harry, W., Zink, K.J., Eds.; Springer: Berlin/Heidelberg, Germany, 2014; pp. 247-271, ISBN 978-3-642-37524-8.

24. Ehnert, I.; Parsa, S.; Roper, I.; Wagner, M.; Muller-Camen, M. Reporting on sustainability and HRM: A comparative study of sustainability reporting practices by the world's largest companies. Int. J. Hum. Resour. Manag. 2016, 27, 88-108. [CrossRef]

25. Ehnert, I. Sustainability Issues in Human Resource Management: Linkages, theoretical approaches, and outlines for an emerging field. In Proceedings of the 21st EIASM Workshop on SHRM, Birmingham, UK, 30-31 March 2006; pp. 30-31.

26. Ehnert, I. Sustainability and human resource management: Reasoning and applications on corporate websites. Eur. J. Int. Manag. 2009, 3, 419-438. [CrossRef]

27. Kramar, R. Beyond strategic human resource management: Is sustainable human resource management the next approach? Int. J. Hum. Resour. Manag. 2014, 25, 1069-1089. [CrossRef]

28. De Prins, P.; Van Beirendonck, L.; De Vos, A.; Segers, J. Sustainable HRM: Bridging theory and practice through the 'Respect Openness Continuity (ROC)'-model. Manag. Rev. 2014, 25, 263-284. [CrossRef] 
29. App, S.; Merk, J.; Büttgen, M. Employer branding: Sustainable HRM as a competitive advantage in the market for high-quality employees. Manag. Rev. 2012, 23, 262-278. [CrossRef]

30. Kozica, A.; Kaiser, S. A sustainability perspective on flexible HRM: How to cope with paradoxes of contingent work. Manag. Rev. 2012, 23, 239-261. [CrossRef]

31. Diaz-Carrion, R.; López-Fernández, M.; Romero-Fernandez, P.M. Developing a sustainable HRM system from a contextual perspective. Corp. Soc. Responsib. Environ. Manag. 2018, 25, 1143-1153. [CrossRef]

32. Järlström, M.; Saru, E.; Vanhala, S. Sustainable human resource management with salience of stakeholders: A top management perspective. J. Bus. Ethics 2016, 152, 703-724. [CrossRef]

33. Järlström, M.; Vanhala, S.; Saru, E. Ethics and Targets of Sustainable HRM and Its Main Stakeholders. In Academy of Management Proceedings; Academy of Management: Briarcliff Manor, NY, USA, 2015; pp. 166-178.

34. Cohen, E.; Taylor, S.; Muller-Camen, M. HRM's Role in Corporate Social and Environmental Sustainability; SHRM Report: Alexandria, VA, USA, 2012.

35. Boudreau, J.W.; Ramstad, P.M. Talentship and the new paradigm for human resource management: From professional practices to strategic talent decision science. People Strateg. 2005, 28, 17.

36. Müller-Christ, G. Sustainable Management: Coping with the Dilemmas of Resource-Oriented Management; Springer: Berlin/Heidelberg, Germany, 2011; ISBN 978-3-642-19164-0.

37. World Commission on Environment and Development. Our Common Future. 1987. Available online: http:/ / www.un-documents.net/our-common-future.pdf (accessed on 4 August 2018).

38. Hahn, T.; Figge, F. Beyond the bounded instrumentality in current corporate sustainability research: Toward an inclusive notion of profitability. J. Bus. Ethics 2011, 104, 325-345. [CrossRef]

39. Bansal, P. Evolving sustainably: A longitudinal study of corporate sustainable development. Straegt. Manag. J. 2005, 26, 197-218. [CrossRef]

40. Dyllick, T.; Hockerts, K. Beyond the business case for corporate sustainability. Bus. Strateg. Environ. 2002, 11, 130-141. [CrossRef]

41. Elkington, J. Partnerships from cannibals with forks: The triple bottom line of 21st-century business. Environ. Qual. Manag. 1998, 8, 37-51. [CrossRef]

42. Taylor, S.; Osland, J.; Egri, C.P. Guest editors' introduction: Introduction to HRM's role in sustainability: Systems, strategies, and practices. Hum. Resour. Manag. 2012, 51, 789-798. [CrossRef]

43. Eurofound. Fifth European Working Conditions Survey; Publications Office of the European Union: Luxembourg, 2012; ISBN 978-92-897-1062-6.

44. Guerci, M.; Pedrini, M. The consensus between Italian HR and sustainability managers on HR management for sustainability-driven change-towards a 'strong'HR management system. Int. J. Hum. Resour. Manag. 2014, 25, 1787-1814. [CrossRef]

45. Docherty, P.; Forslin, J.; Shani, A.B. Creating Sustainable Work Systems: Emerging Perspectives and Practice; Routledge: Cornwall, UK, 2002; ISBN 0-415-28576-3.

46. Docherty, P.; Kira, M.; Shani, A.B. What the world needs now is sustainable work systems. In Creating Sustainable Work Systems. Developing Social Sustainability, 2nd ed.; Docherty, P., Kira, M., Shani, A.B., Eds.; Routledge: London, UK, 2009; pp. 1-21, ISBN 978-0-415-77271-6.

47. Jackson, S.E.; Seo, J. The greening of strategic HRM scholarship. Organ. Manag. J. 2010, 7, 278-290. [CrossRef]

48. Renwick, D.W.; Redman, T.; Maguire, S. Green human resource management: A review and research agenda. Int. J. Manag. Rev. 2013, 15, 1-14. [CrossRef]

49. Bombiak, E.; Marciniuk-Kluska, A. Green Human Resource Management as a Tool for the Sustainable Development of Enterprises: Polish Young Company Experience. Sustainability 2018, 10, 1739. [CrossRef]

50. Becker, W. Are you leading a socially responsible and sustainable human resource function? People Strateg. 2011, 34, 18-23.

51. Shen, J.; Jiuhua Zhu, C. Effects of socially responsible human resource management on employee organizational commitment. Int. J. Hum. Resour. Manag. 2011, 22, 3020-3035. [CrossRef]

52. Barrena-Martinez, J.; López-Fernández, M.; Romero-Fernandez, P.M. Drivers and Barriers in Socially Responsible Human Resource Management. Sustainability 2018, 10, 1532. [CrossRef]

53. Diaz-Carrion, R.; López-Fernández, M.; Romero-Fernandez, P.M. Evidence of different models of socially responsible HRM in Europe. Bus. Ethics: Eur. Rev. 2018. [CrossRef] 
54. Zink, K.J. Designing sustainable work systems: The need for a systems approach. Appl. Ergon. 2014, 45, 126-132. [CrossRef] [PubMed]

55. Guerci, M.; Shani, A.B.R.; Solari, L. A stakeholder perspective for sustainable HRM. In Sustainability and Human Resource Management: Developing Sustainable Business Organizations; Ehnert, I., Harry, W., Zink, K.J., Eds.; Springer: Berlin/Heidelberg, Germany, 2014; pp. 205-223, ISBN 978-3-642-37524-8.

56. Baum, T. Sustainable human resource management as a driver in tourism policy and planning: A serious sin of omission? J. Sust. Tourism 2018, 26, 873-889. [CrossRef]

57. Tabatabaei, S.A.N.; Omran, E.S.; Hashemi, S.; Sedaghat, M. Presenting Sustainable HRM Model Based on Balanced Scorecard in Knowledge-based ICT Companies (The Case of Iran). Econ. Sociol. 2017, 10, 107. [CrossRef]

58. Au, W.C.; Ahmed, P.K. Sustainable people management through work-life balance: A study of the Malaysian Chinese context. Asia Pac. J. Bus. Adm. 2014, 6, 262-280. [CrossRef]

59. Sotome, R.; Takahashi, M. Does the Japanese employment system harm productivity performance? A perspective from DEA-based productivity and sustainable HRM. Asia Pac. J. Bus. Adm. 2014, 6, 225-246. [CrossRef]

60. Mak, A.; Cheung, L.; Mak, A.; Leung, L. Confucian thinking and the implications for sustainability in HRM. Asia Pac. J. Bus. Adm. 2014, 6, 173-189. [CrossRef]

61. Lis, B. The relevance of corporate social responsibility for a sustainable human resource management: An analysis of organizational attractiveness as a determinant in employees' selection of a (potential) employer. Manag. Rev. 2012, 279-295. [CrossRef]

62. Müller-Christ, G.; Remer, A. Umweltwirtschaft oder Wirtschaftsökologie? Vorüberlegungen zu einer Theorie des Ressourcenmanagements. In Betriebliches Umweltmanagement im 21. Jahrhundert; Seidel, E., Ed.; Springer: Berlin/Heidelberg, Germany, 1999; pp. 69-87, ISBN 978-3-642-64320-0.

63. Gollan, P.J. Human resources, capabilities and sustainability. Greenwood, M.R. Ethics and HRM: A review and conceptual analysis. J. Bus. Ethics 2002, 36, 261-278.

64. Gollan, P.J.; Xu, Y. Fostering corporate sustainability. In Sustainability and Human Resource Management: Developing Sustainable Business Organizations; Ehnert, I., Harry, W., Zink, K.J., Eds.; Springer: Berlin/Heidelberg, Germany, 2014; pp. 225-245, ISBN 978-3-642-37524-8.

65. Mariappanadar, S. Sustainable human resource strategy: The sustainable and unsustainable dilemmas of retrenchment. Int. J. Soc. Econ. 2003, 30, 906-923. [CrossRef]

66. Mariappanadar, S. The model of negative externality for sustainable HRM. In Sustainability and Human Resource Management: Developing Sustainable Business Organizations; Ehnert, I., Harry, W., Zink, K.J., Eds.; Springer: Berlin/Heidelberg, Germany, 2014; pp. 181-203, ISBN 978-3-642-37524-8.

67. Mariappanadar, S. Stakeholder harm index: A framework to review work intensification from the critical HRM perspective. Hum. Resour. Manag. Rev. 2014, 24, 313-329. [CrossRef]

68. Smith, W.K.; Lewis, M.W. Toward a theory of paradox: A dynamic equilibrium model of organizing. Acad. Manag. Rev. 2011, 36, 381-403.

69. Mariappanadar, S.; Kramar, R. Sustainable HRM: The synthesis effect of high performance work systems on organisational performance and employee harm. Asia Pac. J. Bus. Adm. 2014, 6, 206-224. [CrossRef]

70. Mariappanadar, S.; Aust, I. The Dark Side of Overwork: An Empirical Evidence of Social Harm of Work from a Sustainable HRM Perspective. Int. Stud. Manag. Organ. 2017, 47, 372-387. [CrossRef]

71. Ehnert, I. Sustainability and HRM: A model and suggestions for future research. In The Future of Employment Relations. New Paradigms, New Developments; Wilkinson, A., Townsend, K., Eds.; Palgrave Macmillan: London, UK, 2011; pp. 215-237, ISBN 978-0-230-24094-0.

72. Browning, V.; Delahaye, B.L. Enhancing workplace learning through collaborative HRD. In Readings in HRM and Sustainability; Clarke, M., Ed.; Tilde University Press: Prahran, Australia, 2011; pp. 36-50, ISBN 978-0-7346-1101-7.

73. Brown, M.; Shields, J. Reward management: Rethinking individual performance pay. In Readings in HRM and Sustainability; Clarke, M., Ed.; Tilde University Press: Prahran, Australia, 2011; pp. 64-81, ISBN 978-0-7346-1101-7.

74. Wells, R. Setting people up for success: Sustainable performance management. In Readings in HRM and Sustainability; Clarke, M., Ed.; Tilde University Press: Prahran, Australia, 2011; pp. 51-63, ISBN 978-0-7346-1101-7. 
75. Donnelly, N.; Proctor-Thomson, S. Workplace sustainability and employee voice. In Readings in HRM and Sustainability; Clarke, M., Ed.; Tilde University Press: Prahran, Australia, 2011; pp. 117-132, ISBN 978-0-7346-1101-7.

76. Hoeppe, J.C. Practitioner's View on Sustainability and HRM. In Sustainability and Human Resource Management: Developing Sustainable Business Organizations; Ehnert, I., Harry, W., Zink, K.J., Eds.; Springer: Berlin/Heidelberg, Germany, 2014; pp. 273-294, ISBN 978-3-642-37524-8.

77. Ministry of Environment of the Republic of Lithuania. Available online: http://www.am.lt/VI/en/VI/ index.php\#r/187 (accessed on 10 October 2018).

78. CSR Network Lithuania. Available online: http://csrbaltic.lt/en/ (accessed on 10 October 2018).

79. Ministry of Social Security and Labour of the Republic of Lithuania. Available online: https://socmin.lrv.lt/ en/ (accessed on 10 October 2018).

80. Migration in Numbers. Available online: http://123.emn.lt/en/\#chart-14-desc (accessed on 10 October 2018).

81. Global Sustainable Sustainable Competitiveness Index. Available online: http://solability.com/the-globalsustainable-competitiveness-index/the-index (accessed on 10 October 2018).

82. Poria, Y.; Reichel, A.; Brandt, Y. Dimensions of hotel experience of people with disabilities: An exploratory study. Int. J. Contemp. Hosp. Manag. 2011, 23, 571-591. [CrossRef]

83. Gläser, J.; Laudel, G. Life with and without coding. Two methods for early-stage data analysis in qualitative research aiming at causal explanations. Forum Qual. Social Res. 2013, 14. [CrossRef]

84. Colaizzi, P.F. Psychological research as the phenomenologist views it. In Existential-Phenomenological Alternatives for Psychology; Valle, R.S., King, M., Eds.; Oxford University Press: New York, NY, USA, 1978; pp. 48-71.

85. Allen, N.J.; Meyer, J.P. The measurement and antecedents of affective, continuance and normative commitment to the organization. J. Occup. Psychol. 1990, 63, 1-18. [CrossRef]

86. Hirsig, N.; Rogovsky, N.; Elkin, M. Enterprise Sustainability and HRM in Small and Medium-Sized Enterprises. In Sustainability and Human Resource Management: Developing Sustainable Business Organizations; Ehnert, I., Harry, W., Zink, K.J., Eds.; Springer: Berlin/Heidelberg, Germany, 2014; pp. 127-152, ISBN 978-3-642-37524-8.

87. Joensson, T. A multidimensional approach to employee participation and the association with social identification in organizations. Empl. Relat. 2008, 30, 594-607. [CrossRef] 